\title{
INWENTARZ ARCHIWUM KURII ARCHIDIECEZJI ORMIAŃSKOKATOLICKIEJ WE LWOWIE ZA LATA 1616-1939
}

\section{Wprowadzenie}

Archidiecezja lwowska obrządku ormiańskokatolickiego sięga swymi początkami wieku XVII, kiedy to 24 X 1630 roku bp Mikołaj Torosowicz złożył we Lwowie wyznanie wiary katolickiej, przechodząc tym samym pod jurysdykcję Stolicy Apostolskiej. Wcześniej, funkcjonowała tam od 1356 roku lwowska diecezja ormiańska, erygowana przez ormiańskiego katolikosa z Sis dla społeczności ormiańskiej osiadłej na Rusi ${ }^{1}$.

Po nawiązaniu unii z Rzymem, inicjatywy pastoralno-organizacyjne kolejnych pasterzy lokalnego Kościoła lwowskiego zmierzały w kierunku reformy struktur organizacyjnych, wprowadzenia kalendarza gregoriańskiego oraz modyfikacji liturgicznych. Pod względem położenia geograficznego, archidiecezja lwowska rozpościerała się na obszarze południowo-wschodniej Rzeczypospolitej. W 1665 roku liczyła 15 parafii, 20 kapłanów i ok. 3000 wiernych. Z biegiem lat stan ten uległ znacznej poprawie; tak np. w 1763 roku funkcjonowało już 18 parafii z blisko 6.000 katolików, a w 1772 roku archidiecezja obejmująca tereny Polski, Litwy, Mołdawii oraz Wołoszczyzny liczyła 22 parafie, 40 kapłanów i ok. 6000 wiernych $^{2}$. Niekorzystne zmiany w tym względzie przyniosły rozbiory Pol-

* Ks. Józef Wołczański - dr hab. historii, prof. PAT, kierownik Katedry Historii Kościoła XIX i XX wieku.

${ }^{1}$ B. Modzelewska, Lwowska diecezja ormiańska, w: Encyklopedia Katolicka (dalej: EK), t. 11, Lublin 2006, kol. 287; J. Szteinke, Lwowska archidiecezja ormiańskokatolicka, EK, t. 11, kol. 285; C. Lechicki, Kościól ormiański w Polsce. (Zarys historyczny), Lwów 1928, s. 50-61; Z. Obertyński, Ormianie, w: Historia Kościoła w Polsce, t. 1, cz. 1, red. B. Kumor, Z. Obertyński, Poznań 1974, s. 256-258; tenże, Unia florencka polskich Ormian, w: Historia Kościoła w Polsce, t. 1, cz. 1, s. 391392; tenże, Unia Ormian polskich, w: Historia Kościoła w Polsce, t. 1, cz. 2, s. 324-340.

2 J. Szteinke, Lwowska archidiecezja, kol. 286; Z. Obertyński, Kościół ormiański. Kryzysy XVIII wieku, w: Historia Kościoła w Polsce, t. 1, cz. 2, s. 480. 
ski w XVIII stuleciu, wskutek czego parafie objęte granicą zaboru rosyjskiego zostały poddane w latach 1809-1816 jurysdycji odrębnego administratora. Z kolei w zaborze austriackim wskutek arbitralnej polityki józefińskiej zlikwidowano 6 parafii ormiańskich, jedną przyznano również wiernym obrządku łacińskiego oraz włączono do lwowskiej archidiecezji 2 parafie z Bukowiny ${ }^{3}$. Dalsze zmiany przyniósł wiek XX. Po traktacie ryskim 1921 roku, a zwłaszcza na mocy konkordatu Rzeczypospolitej Polskiej ze Stolicą Apostolską w 1925 roku, odpadła na rzecz Rumunii Bukowina, a tym samym tamtejsze parafie zostały wyłączone spod jurysdykcji arcybiskupa lwowskiego. Korzystną zmianą był natomiast fakt rozciągnięcia tejże jurysdykcji na obszar całej II Rzeczypospolitej ${ }^{4}$. W okresie międzywojennym 1918-1939 archidiecezja lwowska obrządku ormiańskokatolickiego dysponowała 8 parafiami w ramach 3 dekanatów, 9 kościołami parafialnymi i 19 kaplicami, w których 18 kapłanów sprawowało opiekę religijną nad ok. 5.000 wiernymi (1939). Sieć dekanalno-parafialna przedtawiała się zatem następująco: 1) dekanat lwowski - parafie: Lwów, Brzeżany, 2) dekanat stanisławowski - parafie: Stanisławów, Łysiec, Tyśmienica, 3) dekanat kucki - parafie: Kuty, Horodenka, Śniatyn ${ }^{5}$.

Ważną instytucją lokalnego Kościoła ormiańskokatolickiego była Kapituła Katedralna we Lwowie erygowana dekretem Piusa VII w 1803 roku, dysponująca jedną prałatura, trzema kanoniami gremialnymi oraz czterema kanoniami honorowymi. Taki stan utrzymał się aż do 1945 roku$^{6}$. O żywotności wspólnot parafialnych na przestrzeni wieków świadczyły liczne bractwa i stowarzyszenia religijne i oświatowo-wychowawcze. I tak na poczatku XVIII stulecia we Lwowie funkcjonowały bractwa: Matki Bożej i św. Grzegorza Oświeciciela, w Horodence Niepokalanego Poczęcia Najświętszej Maryi Panny, św. Anny, Różańca Świetego i Szkaplerza, w Kamieńcu Podolskim - św. Anny, w Stanisławowie - Niepokalanego Poczęcia Najświętszej Maryi Panny, św. Anny i św. Grzegorza Oświeciciela. Stosunkowo dobrze prosperowała sieć szkół parafialnych w Łyścu, Stanisławowie i Śniatyniu oraz szpitali parafialnych we lwowie, Kamieńcu Podolskim, Stanisławowie, Śniatyniu i Zamościu7. W latach 1665-1784 prosperowało we Lwowie Papieskie Kolegium Ormiańskie z dotacji rzymskiej Kongregacji Rozkrzewiania Wiary, prowadzone przez księży teatynów. Odbywali w nim formację intelektualno-moralną kandydaci do stanu duchownego; z chwilą likwidacji wspomnianej instytucji almuni znaleźli gościnę w Seminarium Generalnym obrządku łacińskiego we Lwowie do roku 1790, a następnie w rzymskokatolickim Seminarium Duchownym archidiecezji lwowskiej tamże. Studia filozoficzno-teologiczne odbywali na Wydziale Teologicznym Uniwersytetu Lwowskiego. Z myślą o uczą-

${ }^{3}$ Szteinke, Lwowska archidiecezja, kol. 286.

${ }^{4}$ Z. Obertyński, Kościół ormiański, w: Historia Kościoła w Polsce, t. 2, cz. 2, red. B. Kumor, Z. Obertyński, Poznań 1979, s. 84.

${ }^{5}$ Szteinke, Lwowska archidiecezja, kol. 286; Schematismus archidoecesis Leopoliensis ritus armeno-catholici pro anno Domini 1939, Leopoli 1939, passim.

${ }^{6}$ Szteinke, Lwowska archidiecezja, kol. 286; Schematismus [...] 1939, s. 14-15.

${ }^{7}$ Szteinke, Lwowska archidiecezja, kol. 286. 
cej się ubogiej młodzieży męskiej, powołano do życia w drugiej połowie XIX w. Internat im. Józefa Torosiewicza we Lwowie (1865-1939) ${ }^{8}$.

W ciągu wieków rozwijały się również instytucje samopomocowe mniejszości ormiańskiej w Polsce. Za najstarszą a zarazem cieszącą się największym prestiżem uchodził Instytut Mons Pius, powołany do życia w 1640 roku we Lwowie, zajmujący się kwestiami depozytowo-finansowymi Ormian polskich ${ }^{9}$. Na uwagę zasługują również inicjatywy kulturalno-oświatowe i religijne społeczności ormiańskiej we Lwowie. W 1930 roku powołano do życia Archidiecezjalny Związek Ormian. Cenionymi periodykami polskojęzycznymi stały się dwa tytuły: miesięcznik „Posłaniec św. Grzegorza" - wydawany w latach 1927-1934 oraz dwumiesięcznik „Gregoriana”, ukazujący się od 1935 do 1938 roku. Funkcję redaktora naczelnego pełnił w obu tych pismach ks. Dionizy Kajetanowicz ${ }^{10}$. Wreszcie na uwagę zasługuje obecność i działalność w archidiecezji lwowskiej Zakonu ss. Benedyktynek obrządku ormiańskokatolickiego, prowadzących od wieku XVII we Lwowie szkołę żeńską, legitymującą się od 1889 roku prawami państwowymi.

Na przestrzeni czterech wieków, archidiecezją lwowską obrządku ormiańskokatolickiego kierowało 12 arcybiskupów. Byli to: Mikołaj Torosowicz (16271681), Wartan Hunianian (1686-1715), Jan Tobiasz Augustynowicz (1716-1752), Jakub Stefan Augustynowicz (1752-1783), Walerian Tumanowicz (1783-1798), Jan Jakub Szymonowicz (1800-1816), Kajetan Augustyn Warteresiewicz (18201831), Samuel Cyryl Stefanowicz (1832-1858), Grzegorz Michał Szymonowicz (1858-1875), Grzegorz Józef Romaszkan (1876-1881), Izaak Mikołaj Isakowicz (1882-1901), Józef Teofil Teodorowicz (1902-1938) ${ }^{11}$.

Zmierzch istnienia lokalnego Kościoła ormiańskiego we Lwowie nastapił z chwilą śmierci abp. Józefa Teodorowicza 4 XII 1938 roku. Rządy przejął wówczas wikariusz kapitulny ks. infułat Dionizy Kajetanowicz, ale wybuch wojny i zmiany pojałtańskie przeszkodziły Stolicy Apostolskiej w nominacji nowego pasterza. Po zakończeniu II wojny światowej władze sowieckie przystapiły do likwidacji struktur ormiańskiej archidiezji lwowskiej metodą terroru, santażu i aresztowań. Wśród ofiar eksterminacyjnej polityki okupantów znalazł się obok innych duchownych i świeckich m.in. ks. D. Kajetanowicz, aresztowany przez NKGB we Lwowie 26 XI 1945 roku. Na mocy wyroku Trybunału Wojskowego NKGB obwodu lwowskiego z 8 III 1946 roku został skazany na 10 lat łagrów, konfiskatę mienia i pozbawienia praw publicznych na 5 lat. Wywieziony w głąb Rosji, gdzie zmał 18 XI 1954 roku w łagrze Anież na terenie obwodzie Komi

\footnotetext{
${ }^{8}$ Tamże; J. Krętosz, Archidiecezja lwowska obrządku łacińskiego w okresie józefinizmu (17721815), Katowice 1996, s. 154; Schematismus [...] 1939, s. 42.

${ }^{9}$ Schematismus [...] 1939, s. 43.

${ }^{10}$ Bibliografia katolickich czasopism religijnych $w$ Polsce 1918-1944, red. Z. Zieliński, Lublin 1981, s. 121, 229.

${ }^{11}$ W katalogu pasterzy Kościoła ormiańskokatolickiego we Lwowie występuje jeszcze bp Boddan Deodat Nerserowicz, prekonizowany biskupem pomocniczym w 1683 roku, mianowany adminsitratorem apostolskim w 1684 roku, a potem koadiutorem w 1701 roku. Zmarł przed 15 VII 1709 roku. Z. Obertyński, Katalog unickich arcybiskupów ormiańskich w Polsce, w: Historia Kościoła w Polsce, t. 2, cz. 2, s. 312.
} 
ASRS $^{12}$. Jego los podzielili również inni duchowni: kanclerz Kurii Arcybiskupiej ks. Wiktor Kwapiński - aresztowany we Lwowie 26 XI 1945 roku i skazany na analogiczny jak w poprzednim przypadku wyrok ${ }^{13}$; proboszcz w Brzeżanach ks. Kazimierz Romaszkan - aresztowany w Pomorzanach 21 VIII 1945 roku i skazany na 15 lat łagrów, konfiskatę mienia i utratę praw publicznych na lat $5^{14}$; subdiakon zatrudniony prze katedrze we lwowie Stanisław Leopold Drobot - aresztowany tamże 22 X 1945 roku, po czym w trakcie śledztwa zwolniony z więżienia i wydalony w 1946 roku do Polski ${ }^{15}$. Inny duchowny - administrator parafii Brzeżany, ks. Sergiusz Egulian utonął w tajemniczych okolicznościach w miejscowym jeziorze latem 1945 roku $^{16}$. Pozostali księża, jak również laikat zmuszeni do opuszczenia swych siedzib w Małopolsce Wschodniej, po części trafili do więzień, po części zostali ekspatriowani do Polski. Katedra lwowska jak również pozostałe światynie ormiańskie zostały zamknięte, a instytucje zlikwidowane. Tym samym ormiańskokatolicka archidiecezja lwowska przestała istnieć, choć Stolica Apostolska nigdy nie anulowała jej formalnie ${ }^{17}$.

Publikowany niżej inwentarz archiwaliów Kurii Archidiecezji Lwowskiej obrządku ormiańskokatolickiego zawiera źródła przechowywane w chwili obecnej w Państwowym Centralnym Archiwum Historycznym Ukrainy we Lwowie. Zawiera 958 jednostek inwentarzowych w kilkunastu działach tematycznych:

1) Protokoły posiedzeń Konsystorza (Kurii) i kolegium biskupów

2) Dekrety królewskie w sprawach Kościoła ormiańskokatolickiego

3) Źródła do dziejów Ormian i Kościoła ormiańskokatolickiego

4) Listy pasterskie biskupów

5) Dekrety lwowskiego Gubernatorstwa, Namiestnictwa Galicyjskiego i wiedeńskich ministerstw

6) Rozporządzenia i korespondencja Kurii z instytucjami państwowymi na szczeblu centralnym i lokalnym

7) Uroczystości kościelno-religijne

8) Funkcjonowanie parafii i świątyń

9) Kwestie majątkowo-gospodarcze

${ }^{12} \mathrm{~J}$. Wołczański, Martyrologium księży ormiańskokatolickich $w$ archidiecezji lwowskiej po II wojnie światowej w świetle źródet sowieckich, w: Polacy w Armenii, red. E. Walewander, Lublin 2000, s. $201 \mathrm{nn}$.; R. Dzwonkowski, Leksykon duchowieństwa polskiego represjonowanego w ZSRS 1939-1988, Lublin 2003, s. 304-305.

${ }^{13}$ W łagrach spędził jedynie dwa lata, uzyskując zwolnienie 9 IX 1948 roku, po czym wydalono go do Polski. Wołczański, Martyrologium, s. 204; Dzwonkowski, Leksykon, s. 369-370.

${ }^{14}$ Zwolniony z łagrów w Norylsku 25 X 1955 roku, wyjechał do Polski. Wołczański, Martyrologium, s. 193-194; Dzwonkowski, Leksykon, s. 515-516 (błąd w datacji dziennej aresztowania i miejsca).

${ }^{15}$ Wołczański, Martyrologium, s. 199-200; Dzwonkowski, Leksykon, s. 201-202.

${ }^{16}$ T. Zaleski, Stownik biograficzny duchownych ormiańkokatolickich oraz duchownych rzymskokatolickich pochodzenia ormiańskiego w Polsce w latach 1750-2000, Kraków 2001, s. 46.

${ }^{17}$ Aktualnie na terenie Ukrainy funkcjonuje erygowana 10 I 1997 roku diecezja ormiańska Apostolskiego Kościoła Ormiańskiego, podlegająca katolikosowi Eczmiadzynu. We Lwowie rezyduje bp Natan Oganesian, celebrując nabożeństwa w odzyskanej w 2001 roku katedrze; jego jurysdykcji podlega 11 parafii (1997). Modzelewska, Lwowska diecezja ormiańska, kol. 287. 
10) Budownictwo sakralne

11) Klasztor ss. Benedyktynek obrządku ormiańskokatolickiego

12) Zakłady naukowo-wychowawcze

13) Współpraca ze stowarzyszeniami

14) Dokumenty personalne

15) Działalność „medialna”

16) Archiwalia różne.

Prezentowane materiały zostały zawłaszczone prawdopodobnie w 1945 roku przez władze sowieckie po likwidacji struktur organizacyjnych archidiecezji lwowskiej. $Z$ całą pewnością kolekcja ta nie zawiera całości spuścizny archiwalnej wytworzonej w ciagu wieków przez lokalny Kościół ormiańskokatolicki. Trudno dziś ustalić stan ówczesnych zasobów przejmowanych przez czynniki sowieckie, a z drugiej strony pewnym jest fakt dekompozycji zbiorów, spośród których wyłączano np. pergamniny, tworząc $\mathrm{z}$ nich $\mathrm{w}$ połączeniu $\mathrm{z}$ materiałami o innej proweniencji całkiem odbrębne kolekcje w archiwach sowieckich po 1945 $\mathrm{roku}^{18}$. Pomimo dość szczegółowych metryk poszczególnych jednostek inwentarzowych sporządzonych w języku ukraińśkim, często nie korespondują one z zawartością poszytów. Prawdopodobnie sporządzały je osoby bez dostetecznej znajomości języków, którymi posługiwano się podczas wytwarzania dokumentów: ormiańskiego, łacińskiego, polskiego i niemieckiego.

W niniejszej publikacji zachowano oryginalny układ inwentarza znajdującego się we wspomnianej ukraińskiej instytucji we Lwowie, jak również zaniechano jakichkolwiek ingerencji stylistyczno-językowych.

\section{Publikacja inwentarza}

\section{ЦЕНТРАЛЬНИЙ ДЕРЖАВНИЙ ІСТОРИЧНИЙ АРХІВ УКРАЇНИ м. ЛЬВІВ ВІРМЕНСЬКА МИТРОПОЛИЧА КОНСИСТОРІЯ м. ЛЬВІВ 1616-1939 pp.}

ФОНД № 475

ОПИС № 1

\section{ПРОТОКОЛИ ЗАСІДАНЬ КОНСИСТОРІЇ ТА КОМІТЕТУ СПИСКОПІВ}

1. Протоколи засідань консисторії; 1833-1836

2. Протокол засідання комітету єпископів вірменського, греко і римокатолицького віросповідань; 1925

\footnotetext{
${ }^{18}$ Informacje własne autora.
} 


\section{ОРОЛІВСЬКІ ПОСТАНОВИ, ДЕКРЕТИ, ПРИВІЛЁ̈, РОЗПОРЯ- ДЖЕННЯ, ПОДАННЯ, ЗАЯВИ, КАСАЦІЙНІ СКАРГИ ТА ІНШІДО- КУМЕНТИ ПРО ЮРИСДИКЦІЮ ВІРМЕНСЬКОЇ ЦЕРКВИ}

3. Подання вірменського архієпископа Никоровича Г. Галицькому губернаторові про надання вірменам рівних прав з римо-католиками; 1774

4. Заяви, касаційні скарги, протоколи засідань та ін[ші] документи про діяльність вірменського Духовного суду у Львові; 1780-1793

5. Королівські постанови, директиви, привілеї та ін[ші] документи про надання прав вірменській юрисдикції - копії; 1782

6. Розпорядження і листи Крайового губернаторства у Львові про юрисдикцію вірменською церкви, релігійні і обрядові практики священиків, ведення майнових справ та ін[ші] - том I; 1785

7. Те ж- том II і останній; 1785

8. Виписка з земських книг про права і привілеї вірменського костьолу в Луцьку; 1787

9. Листування с Крайовим губернаторством у Львові про надання прав вірменському єпископству Трансільванії, виділення ії в окрему церковну адміністративну громаду та ін[ші] питання; 1787

10. Розпорядження про права і обов'язки вірменських костьолів в Галичині та на Буковині; 1814-1816

11. Послання австрійському монархові про релігійні та правові стосунки та матеріальне забезпечення вірменських костьолів; 1821

12. Листування з Крайовим губернаторством і крайовим урядом Буковини про права і обов'язки вірменських костьолів, об'єднання парафіян вірменської національності, заснування вірменських шкіл в Галичині та на Буковині; 1822-1829

13. Розпорядження, інструкції, листування та ін[ші] документи про заснування і надання юридичних прав вірменським парафіянам в Галичині $\mathrm{i}$ на Буковині; 1835-1840

14. Листування з Галицьким намісництвом та ін[ші] установами Львова про вирішення правових питань священиків і капеланів, надання допомоги інвалідам військовим та ін.; 1851-1859

15. Протоколи, відозви, листування та ін[ші] документи про звільнення графа Потоцького С. від патронату над вірменською церквою у Бережанах; 1860-1864

16. Лист президії Вищого крайового суду у Львові про вибори в громадах третейських судів для вирішення суперечок між населенням; 1913

17. Обіжник Голови Ради міністрів у Варшаві про ліквідацію інструкції, яка суперечить постанові конкордату; 1925 


\section{ПОСЛАННЯ, ЛИСТИ, СТАТІ, ІНФОРМАЦІЯ, ДОПОВІДЬ, КОНС- ПЕКТИ З ІСТОРІЇ ВІРМЕНСЬКОГО НАРОДУ ТА ЦЕРКВИ}

18. Послання та листи священнослужителів про історію вірменського народу і митрополичої консисторії у Львові, вживання вірменської мови в релігійних обрядах на Буковині, надання матеріальної допомоги вірменським колоніям та ін[ші]; 1732-1929

19. Листування з Папською курією у Римі про введення григоріанського календаря; 1783-1785

20. Статті про історію та культуру Вірменії; 1796-1878

21. Книга про життя святих; сер. XVIII ст.

22. Збірник молитв; XVIII ст.

23. Інформація про історію вірменського костьолу у Львові та інвентарні описи майна; 1807-1811

24. Лист до Крайового губернаторства у Львові про об'єднання римо-католицького та вірменського костьолів у Тисмениці; 1812

25. Лист священика Мошоро С. про історію релігії вірменського народу копія; 1814

26. Лист священнослужителя Богдановича Р. 3 м. Бережан про відродження національного и культурно-суспільного життя вірменського народу; 1877

27. Доповідь священика Алішана про життя і діяльність вірменського діяча Гаїка та ін[ші] статті про історичне та культурне життя Вірменії; 1880

28. Статут архікафедрального вірменського капітулу у Львові; 1895

29. Нарис професора Теодоровича А. „Вірменія”; 1897

30. Конспект з вірменської мови фрагменти; XIX ст.

31. Конспект невстановленого автора з книги Вебера С. „Католицька церква у Вірменіï"; 1903

32. Конспект з історії церкви невстановленого автора; б/д

\section{ПАСТИРСЬКІ ПОСЛАННЯ ТА ЛИСТИ ПРО ЗМІЦЕННЯ КАТО- ЛИЦЬКОї ВІРИ}

33. Пастирські послання та листи про зміцнення католицької віри та зв’язок з папською курією; 1781-1807

34. Папські послання та пастирські листи про зміцнення католицької віри, зв'язок з папською курією, навчання в школах релігії та ін[ші]; 1819, $1832-1850$

35. Папські і пастирські послання про зміцнення католицької віри, зв’язок 3 папською курією та ін[ші]; 1820-1834

36. Папські послання та пастирські листи про зміцнення католицької віри, зв'язок з папською курією та ін[ші]; 1851-1859

37. Папські послання та пастирські листи про зміцнення католицької віри, навчання в школах релігії та ін[ші]; 1860-1873 
38. Пастирські послання та листи про зміцнення католицької віри і надання дозволу на звільнення від посту окремих віруючих; 1923-1925

\section{ПАСТИРСЬКІ ПОСЛАННЯ, ПРОПОВІДІ, СТАТТІ, НАРИСИ, ЛИСТУ- ВАННЯ ТА ІН[ШІ] ДОКУМЕНТИ МИТРОПОЛИТІВ І ЄПИС- КОПІВ}

Авггустиновича Якова

39. Лист папської нунціатури у Відні вірменському архієпископу Августиновичу Я. про публікацію папської булли, присвяченої ювілею папи Климентія XIV; 1774

Більчев ського Йоси иа

40. Лити священиків і парафіян 3 протестами проти публікації в газеті „Монітор” статті спрямованні проти митрополита Більчевського і єпископа Теодоровича; 1907

41. Анкета запитань про життя митрополита Більчевського Й.; 1938

Вартануса Гунаніана

42. Свідоцтво видане архієпископом Вартанусом Г. про складення екзамену на звання священика Дерторосовичем Г.; 1690

В ар т ар асев и ча Кає тана

43. Інвентарний опис бібліотеки архієпископа Вартарасевича К.; б/д

I с акович а I c а ака Миколи

44. Пастирські послання та листи архієпископа Ісаковича I. М. про зміцнення католицької віри, релігійні і обрядові практики священиків та ін[ші]; 1882-1889

45. Те ж; 1890-1901

46. Проповіді митрополита Ісаковича I. М. - том I; б/д

47. Те ж- том II і останній; б/д

48. Телеграми з приводу смерті архієпископа Ісаковича I. М.; 1901

Сте фановича Самуеля Кирила

49. Пастирські послання архієпископа Стефановича С. К. про зміцнення католицької віри, проведення релігійних і обрядових практик та ін[ші]; 1832-1835

50. Пастирські послання та листи архієпископа Стефановича С. К. про зміцнення католицької віри, зв'язок 3 папською курією, обрядові i релігійні практики священиків та ін[ші]; 1836-1840

51. Те ж; 1841-1850

Те одоровича Йосипа

52. Особова справа митрополита Теодоровича Й.; 1882-1837

53. Листи католицьких товариств у Львові про призначення своїм членом митрополита Теодоровича Й.; 1898-1901

54. Статті з історії та релігії митрополита Теодоровича Й.; б/д

55. Нариси з поїздки по Італії митрополита Теодоровича Й.; б/д

56. Проповіді митрополита Теодоровича Й. - том I; б/д

57. Те ж- том II; б/д 
58. Те ж- том III; б/д

59. Те ж-том IV; б/д

60. Те ж-том V; б/д

61. Те ж-том VI; б/д

62. Те ж-том VII; б/д

63. Те ж-том VIII; б/д

64. Те ж-том IX; б/д

65. Те ж-том X; б/д

66. Те ж-том XI; б/д

67. Те ж-том XII; б/д

68. Те ж-том XIII; б/д

69. Те ж-том XIV; б/д

70. Те ж-том XV; б/д

71. Те ж-том XVI; б/д

72. Те ж-том XVII; б/д

73. Те ж- том XVIII; б/д

74. Те ж-том XIX; б/д

75. Те ж-том XX; б/д

76. Те ж-том XXI; б/д

77. Те ж-том XXII; б/д

78. Те ж-том XXIII; б/д

79. Те ж-том XXIV; б/д

80. Те ж-том XXV; б/д

81. Те ж-том XXVI; б/д

82. Те ж-том XXVII; б/д

83. Те ж-том XXVIII; б/д

84. Те ж-том XXIX; б/д

85. Те ж-том XXX і останній; б/д

Торосевича Миколи

86. Інформація королівського секретаря папському нунцію у Варшаві про діяльність єпископа Торосевича М.; 1645

Тумановича Якуба

87. Повідомлення та листування про визначні події в Австрійській державі та призначення архієпископом священика Тумановича Я; 1784-1790

Ши моновича Григорія

88. Листування з Галицьким намісництвом у Львові про смерть архієпископа Шимановича Г. і вироби нового кандидата на посаду; 1875

89. Дані про зловживання службовими обов'язками вірменськими єпископами; 1637

90. Звернення римо-католицьких єпископів Австрії до Франца-Йосифа I; 1815,1861

91. Тексти єпископських послань і проповідей до духовенства і світських осіб; $1833-1868$ 
РОЗПОРЯДЖЕННЯ, ОБІЖНИКИ, ПОВІДОМЛЕННЯ, ЛИСТУВАННЯ ТА ІН[ШІ] ДОКУМЕНТИ КРАЙОВОГО ГУБЕРНАТОРСТВА, ГАЛИЦЬКОГО НАМІСНИЦТВА, МІНІСТЕРСТВ ТА ІН[ШІ] 3 ПИTАНЬ:

I. Юрисдикції, ведення майнових справ, релігійних і обрядових практик, церковних урочистостей, поширення релігійної пропаганди, підготовки шематизмів, адміністративно-господарської i фінансової діяльності, особового складу та ін[ші]

92. Розпорядження і листи губернатора Галичини Бригідо Й. про матеріальне забезпечення священиків, їх навчання та надання дотацій; 1783

93. Розпорядження і листи Крайового губернаторства у Львові про фонди, платню і дотацію священикам, ведення метричних книг та ін[ші]; 1783$-1784$

94. Розпорядження і листи губернатора Галичини Бригідо Й. про надання допомоги потерпілим від стихійного лиха, оголошення конкурсів на посади священиків, надання їм дотацій та ін[ші]; 1784

95. Те ж про релігійні та обрядові практики, нарахування податків, ведення метричних книг та ін[ші]; 1784

96. Те ж про призначення на посади священиків, підготовку шематизмів, ведення метричних книг та ін[ші]; 1784

97. Розпорядження і листи губернатора Галичини Бригідо Й. про навчання в духовній семінарії, платню і дотації священикам, фінансові, податкові справи та ін[ші]; 1784

98. Те ж про платню і дотацію священикам, призначення на посади, фінансові, податкові справи та ін[ші]; 1784

99. Те ж про надання дотацій священикам, навчання релігії в школах, ведення метричних і майнових книг та ін[ші]; 1785

100. Те ж про релігійні і обрядові практики священиків, призначення на посади і їх навчання та ін[ші]; 1786

101. Те ж про навчання релігії в школах, призначення церковних легатів, фінансові і податкові справи та ін[ші]; 1786

102. Розпорядження і листи крайового губернаторства у Львові про будівництво костьолів, парафіяльних будинків, платню і дотації священикам, навчання релігії в школі та ін[ші]; 1786-1787

103. Розпорядження і листування губернатора Галичини Бригідо Й. про призначення сестер новіціаток в жіночий монастир Бенедектинок, навчання релігії в школах, видання церковних збірок та ін[ші]; 1787-1788

104. Те ж про призначення на посади священиків, заснування ломбардного банку „Піус Монс”, фінансові справи та ін[ші]; 1787

105. Листування з Крайовим губернаторством, Галицьким намісництвом, Магістратом Львова про заснування і діяльність закладу для бідних; $1787-1857$ 
106. Розпорядження і листування губернатора Галичини Бригідо Й. про ведення метричних книг, надання юрисдикції семигородським вірменам, релігійні і обрядові практики священиків та ін[ші]; 1789

107. Те ж про діяльність жіночого монастиря Бенедектинок, навчання релігії в початкових школах, оголошення конкурсу на посади священиків та ін[ші]; 1789

108. Розпорядження і листи Крайового губернаторства у Львові про фінансову діяльність, ведення майнових справ, обрядові і релігійні практики священиків та ін[ші]; 1790

109. Розпорядження і листування губернатора Галичини Бригідо Й. про фінансові і майнові справи, діяльність закладу для бідних та ін[ші]; 1890

110. Розпорядження австрійського уряду про права і обов'язки священиків, поширення релігійної пропаганди серед населення та ін. питання; 1891

111. Розпорядження і листування Крайового губернаторства у Львові про ведення навчання в духовній семінарії, призначення на посади священиків, майнові і фінансові справи та ін[ші]; 1791

112. Розпорядження губернатора Галичини Бригідо Й. про надання дотацій слухачам теологічних студій, фінансові і майнові справи та ін[ші]; 1792

113. Розпорядження і листи крайового губернаторства у Львові відзначення урочистих дат, ведення шкільного діловодства, призначення на посади священиків, фінансові, майнові справи та ін[ші]; 1792

114. Розпорядження і листування губернатора Галичини Бригідо Й. про релігійні і обрядові практики священиків, стягнення податків, надання допомоги потерпілим від стихійного лиха та ін[ші]; 1793

115. Листування з Крайовим губернаторством у Львові про моральний стан населення, поширення релігійної пропаганди та ін[ші]; 1794-1847

116. Те ж про заборону селянам без дозволу поміщика переходити в інші повіти; 1798-1810

117. Повідомлення, оголошення, листування та ін[ші] документи про перепис населення в Галичині та на Буковині і участь у цьому духовенства; $1807-1880$

118. Листування з Крайовим губернаторством про встановлення негласного нагляду за духовними та світськими особами; 1812-1815

119. Розпорядження Крайового губернаторства у Львові про заборону проведення мироприємств в дні релігійних свят; 1812-1816

120. Розпорядження крайового губернаторства у Львові про ведення земельних справ парафій; 1814

121. Те ж про участь духовенства у заходах проти порушень громадського порядку; 1815

122. Розпорядження, зведення, повідомлення та ін[ші] документи про проведення католицької місії в мм. Сучава і Чернівці; 1824-1835

123. Розпорядження крайового губернаторства у Львові про пожертвування для костьолів та церков; 1834 
124. Повідомлення Губернського управління у Львові про надіслання „Провінціальної збірки законів"; 1833-1834

125. Повідомлення Крайового губернаторства у Львові про дозвіл на аудієнцію у австрійського монарха; 1835

126. Обіжники, розпорядження та листування про роботу залізничного і водного транспорту та торгівельні справи; 1842-1850

127. Розпорядження, повідомлення, листування та ін[ші] документи про розшук політично підозрілих осіб та карних злочинців; 1843-1889

128. Обіжники, розпорядження, листування та ін[ші] документи про збільшення сільськогосподарської і промислової продукції та організацію кооперативних і торговельних спілок; 1851-1857

129. Повідомлення та листування про збільшення сільськогосподарської і промислової продукції та ін[ші]; 1861-1870

130. Листування з Галицьким намісництвом у Львові про заборону в костьолах співати релігійні пісні антидержавного змісту; 1861

131. Розпорядження і повідомлення Дирекції поліції про вуличні страйки у Львові; 1861-1864

132. Повідомлення Галицького намісництва у Львові про католицькі місії у Центральній Африці; 1872-1873

133. Листування з Галицьким намісництвом про навчання релігії неповнолітніх правопорушників та призначення экзаменатора для в'язнів; $1873,1905-1907$

134. Обіжник Галицького намісництва у Львові про оформлення записів в іпотечних книгах; 1878

135. Розпорядження Буковинського крайового управління у Чернівцях про організацію опіки над вдовами і сиротами; 1896

136. Листування з Галицьким намісництвом про запровадження середньоєвропейського часу; 1899

137. Повідомлення Галицького намісництва про участь священиків в організації опіки над бідними дітьми та сиротами; 1901-1905

138. Розпорядження Галицького намісництва у Львові та листування з парафіяльними управліннями про збір коштів на релігійні потреби; 1902$-1905$

139. Обіжники та листування про залучення священиків до допомоги на випадок війни; 1902-1911

140. Розпорядження Галицького намісництва у Львові про заборону проведення культурних мироприємств у дні релігійних свят; 1905

141. Розпорядження Міністерства віросповідань і освіти, списки, листування та ін[ші] про переселення вірменських сімей з м. Кути до с. Баніли на Буковині; 1907-1911

142. Лист Палати адвокатів у Кракові про зловживання окремих юридичних осіб стосовно галицьких емігрантів в Америці; 1913

143. Обіжники Міністерства культури і освіти у Відні про заборону ввозу імпортних харчових товарів, поповнення армії з резервного складу та ін[ші]; 1918 
144. Інтерпеляція і листи про заборону поєдинків; 1923

145. Розпорядження віросповідань і освіти, листування та ін[ші] документи про поширення релігійної пропаганди серед населення; 1929-1931

146. Розпорядження магістрату Львова про надання допомоги бідному населенню та боротьбу з жебрацтвом; 1929

147. Обіжник Міністерства віросповідань і освіти про ведення священиками проповідей по збереженню державного майна; 1930

148. Повідомлення головного статистичного управління у Варшаві про стан сільськогосподарської продукції; 1930-1931

149. Лист директора державних архівів Польщі про переговори з австрійським урядом в справі передачі церковних архівних фондів; 1930

\section{II. Організація політичного та адміністративного управління, терито-} ріального поділу

150. Повідомлення губернаторства у Львові про адміністративну реорганізацію Галичини; 1802-1811

151. Розпорядження про об’єднання парафій коломийського і Кутського повітів; 1816

152. Повідомлення та розпорядження Крайової президії у Львові про адміністративну реорганізацію в Галичині та на Буковині; 1854-1860

153. Листування з Президією Галицького намісництва у Львові про організацію політичного і адміністративного управління; 1861-1862

154. Листування з Митрополичим ординаріатом у Львові і Буковинським крайовим управлінням про територіальну приналежність вірменських парафій в Галичині та на Буковині; 1896-1898

155. Повідомлення Галицького намісництва про створення нового староства у Зборові; 1904

156. Листування 3 Львівським воєводством про територіальний поділ вірменської архідієцезії; 1923-1924

III. Призначення на посади службовців та представників вірменської національності, нагороди за працю, надання титулів і гербів

157. Листування з Крайовим губернаторством про призначення на посади представників вірменської національності до Магістрату Львова та ін[ші]; 1780-1786

158. Обіжник та розпорядження Крайового губернаторства про призначення австрійських службовців; 1801-1811

159. Розпорядження Крайового губернаторства у Львові про надання титулів і гербів окремим особам і місцевостям; 1815

160. Розпорядження та повідомлення Крайового губернаторства про призначення на посади австрійських службовців; 1815-1816

161. Обіжники розпорядження та листування про призначення на посади та подання на нагороди державних службовців; 1821-1829 
162. Повідомлення Галицького губернського управління про зміни в персональному складі державних установ; 1832-1835

163. Обіжники і розпорядження Крайового губернаторства про призначення на посади та подання на нагороди державних службовців; 18351840

164. Обіжники та розпорядження Галицького намісництва про призначення на посади та подання на нагороди державних службовців; 1843-1849

165. Обіжники і розпорядження Галицького намісництва та Крайової президії Буковини про призначення на посади та подання на нагороди державних службовців; 1862-1883

166. Повідомлення фінансової прокураторії про призначення італійського консула у Львові; 1908

167. Листування з староством у м. Станіславі про визнання шляхетства Торосевичам Миколі та Климентію; 1913

168. Повідомлення Президіального відділу Львівського воєводського управління про призначення львівського воєводи та його заступника; 1923-1924

169. Лист парафіянина Олійника з Перемишля до архієпископа про підтримку кандидатури його сина на посаду судового службовця; 1925

\section{РОЗПОРЯДЖЕННЯ, ПОВІДОМЛЕННЯ, ВІДОЗВИ ТА ЛИСТУ- ВАННЯ ПРО ВИБОРИ ДО СЕЙМУ, ПАРЛАМЕНТУ, МІСЬКОЇ РАДИ ТА УЧАСТЬ В НИХ ВІРМЕНСЬКОГО ДУХОВЕНСТВА}

170. Повідомлення Крайового губернаторства у Львові про вибори митрополита до виконавчого комітету Станового сейму та призначення дотацій; 1824-1828

171. Листування з Крайовим губернаторством про скликання Станового сейму у Львові і вибори в депутати священика Якубовича М.; 1835$-1840$

172. Розпорядження, повідомлення, листування та ін[ші] документи про скликання Крайового сейму у Львові; 1841-1849

173. Промова Франца Йосипа I на урочистому відкритті Державної ради у Відні; 1861

174. Лист австрійського міністра у Відні про скликання парламентарного представництва народів Австрії; 1861

175. Оголошення, інструкції, листування та ін[ші] документи про вибори до австрійського парламенту і магістрату Львова та участь в них вірменського духовенства; 1861-1870

176. Повідомлення, відозви, листування та ін[ші] документи про вибори депутатів до Крайового сейму та міської ради у Львові; 1872-1878

177. Те ж; $1880-1889$

178. Те ж; 1891-1898

179. Те ж; 1901-1910 
180. Повідомлення про перенесення засідання Державної ради у Відні; 1903

181. Відозва єпископів Галичини про вироби до австрійського парламенту; 1913

182. Листування з Магістратом м. Львова про вибори духовенством депутатів до Крайового сейму; 1913-1918

183. Лист парафіян м. Кути про надання дозволу священику Манугевичу С. балотуватися на сенатора у виборах до сейму і сенату; б/д

\section{РОЗПОРЯДЖЕННЯ, ПОВІДОМЛЕННЯ ТА ЛИСТУВАННЯ ПРО ЦЕРКОВНІ УРОЧИСТОСТІ 3 НАГОДИ ВИЗНАНИХ ПОДІЙ}

184. Повідомлення Галицького губернського управління у Львові про визначні події в Австрійській державі і Габсбурській родині та пов'язанні 3 ними церковні урочистості; 1801-1811

185. Те ж; 1821-1829

186. Повідомлення та листування про визначні події в Австрійській державі та пов'язанні з ними церковні урочистості; 1830-1834

187. Те ж; $1835-1838$

188. Те ж; $1840-1842$

189. Те ж; 1843-1849

190. Те ж; 1851-1859

191. Повідомлення Галицького намісництва про визначні події в Австрійській державі; 1861-1868

192. Листування з Галицьким намісництвом, парафіяльними правліннями та ін[шими] установами Львова про відзначення історичних подій та ювілейних дат світських та духовних осіб; 1870-1879

193. Те ж; $1880-1883$

194. Повідомлення та листування про відзначення ювілейної дати діяльності Римського Папи Льва XIII; 1886-1888

195. Листування з Галицьким намісництвом у Львові, парафіяльними правліннями та ін[шими] установами про відзначення історичних подій та ювілейних дат світських та духовних осіб; 1887-1888

196. Те ж; 1890-1895

197. Те ж; 1896-1898

198. Те ж; 1901-1910

199. Повідомлення парафіяльним правлінням про відзначення видатних подій $з$ життя австрійських монархів; 1903-1904

200. Обіжник Крайової шкільної ради у Львові про святкування учнями річниці Міланського указу; 1913

201. Листування 3 Галицьким намісництвом, Магістратом м. Львова та ін[шими] установами про урочисте відзначення історичних подій і ювілейних дат духовних і світських осіб; 1913-1918 
202. Розпорядження, повідомлення, листування та ін[ші] документи про відзначення визначних історичних подій та ювілейних дат світських та духовних осіб; 1923-1931

203. Повідомлення Львівського воєводського управління про прибуття до Львова президента Польщі; 1924

204. Звернення воєводського комітету до архієпископа Теодоровича у Львові про призначення ним урочистих богослужінь, присвячених тижневі „Ліги повітряної і протигазової оборони”; 1931

\section{ДОКУМЕНТИ ДІЯЛЬНОСТІ ПАРАФІЙ І КОСТЬОЛІВ}

\section{І. Витяги 3 актових книг, звіти, інформації та листування про діяль- ність}

205. Витяги з актових книг консисторії про діяльність вірменських парафій; 1773-1775

206. Звіт про діяльність вірменських парафій у Львівському, Станіславському і Тернопільському воєводствах; 1782

207. Звіти про перевірку діяльності парафій в Галичині і на Буковині; 1791

208. Листування з Крайовим губернаторством у Львові та ін[шими] установами про заснування і діяльність вірменських парафій в Галичині і на Буковині та ін[ші]; 1795-1800

209. Звіти про перевірку діяльності парафій в Галичині і на Буковині; 1821$-1839$

210. Те ж; $1841-1845$

211. Те ж; $1846-1850$

212. Те ж; 1851-1864

213. Листування 3 „Конгрегацією де Пропаганда Фіде” у Римі та ін[шими] установами про стан дієцезій та необхідність проведення перевірок діяльності костьолів; 1874-1895

214. Листування з Галицьким намісництвом у Львові та ін[шими] установами про перевірку діяльності парафій; 1892-1895

215. Розпорядження Галицького намісництва у Львові та листування з парафіяльними правліннями про вибори парафіяльного комітету; 1893$-1907$

216. Повідомлення про приїзд духовних осіб для перевірки діяльності парафій в м.м. Городенці і Чернівцях; б/д

217. Інформація про діяльність вірменського костьолу в м. Кутах; 1802

218. Лист Плюжинського А. про стан католицьких костьолів в Люблінському воєводстві; 1915

219. Протокол перевірки діяльності костьолу в м. Тисьмениці; 1879

220. Листування з Буковинським Крайовим управлінням про діяльність вірменського костьолу в м. Чернівцях; 1914 
II. Розпорядження, інструкції, заяви, листування про оформлення записів в метричних книгах, споріднені одруження, зміну віросповідання видачу свідоцтв

221. Розпорядження, заяви, листування та ін. документи на дозвіл на споріднені одруження, оформлення розлучень та ін[ші]; 1784-1789

222. Те ж; 1790-1800

223. Розпорядження, листування та ін[ши] документи про ведення метричних книг; 1791-1800

224. Те ж; 1801-1816

225. Розпорядження, заяви, листування та ін[ші] документи на дозвіл на споріднені одруження; 1801-1811

226. Розпорядження та листування про зміну віросповідання окремих осіб; 1812-1835

227. Розпорядження, заяви, листування та ін[ші] документи про дозвіл на споріднені одруження; 1812-1815

228. Розпорядження, інструкції та листування про видачу копій з метричних книг; 1819-1830

229. Розпорядження, заяви, листування та ін[ші] документи про дозвіл на споріднені одруження; 1820-1827

230. Те ж; 1828-1829

231. Листування з церковними установами про оформлення записів у метричних книгах; 1830-1835

232. Розпорядження, заяви, листування та ін[ші] документи про дозвіл на споріднені одруження; 1830-1832

233. Те ж; 1833-1834

234. Розпорядження, заяви, листування та ін[ші] документи про оформлення записів в метричних книгах, зміну віросповідання, видачу свідоцтв; 1835-1840

235. Розпорядження, листування та ін[ші] документи про дозвіл на споріднені одруження; 1835-1837

236. Те ж; 1838-1840

237. Розпорядження, заяви, листування та ін[ші] документи про оформлення записів в метричних книгах, зміну віросповідання, видачу свідоцтв; 1841-1842

238. Розпорядження, заяви, листування та ін[ші] документи про дозвіл на споріднені одруження; 1841-1842

239. Те ж; 1843-1845

240. Те ж; 1846-1845

241. Розпорядження, заяви, листування та ін[ші] документи про оформлення записів в метричних книгах, зміну віросповідання, видачу свідоцтв; 1851-1859

242. Розпорядження, заяви, листування та ін[ші] документи про дозвіл на споріднені одруження; 1851-1855

243. Те ж; 1856-1857 
244. Те ж; $1858-1859$

245. Розпорядження, заяви, листування та ін[ші] документи про оформлення записів в метричних книгах, зміну віросповідання, видачу свідоцтв; $1860-1870$

246. Розпорядження, заяви, листування та ін[ші] документи на дозвіл на споріднені одруження; 1861-1867

247. Те ж; $1868-1870$

248. Розпорядження, заяви, листування та ін[ші] документи про оформлення записів в метричних книгах, зміну віросповідання, видачу свідоцтв; $1872-1878$

249. Розпорядження, заяви, листування та ін[ші] документи на дозвіл на споріднені одруження; 1872-1878

250. Розпорядження, заяви, листування та ін[ші] документи про оформлення записів в метричних книгах, зміну віросповідання, видачу свідоцтв; 1880-1884

251. Розпорядження, заяви, листування та ін[ші] документи на дозвіл на споріднені одруження; 1880-1884

252. Розпорядження, заяви, листування та ін[ші] документи про оформлення записів в метричних книгах, зміну віросповідання, видачу свідоцтв та ін[ши]; 1887-1889

253. Розпорядження, заяви, листування та ін[ші] документи на дозвіл на споріднені одруження; 1887-1889

254. Розпорядження, заяви, листування та ін[ші] документи про оформлення записів в метричних книгах, зміну віросповідання, видачу свідоцтв та ін[ши]; 1890-1896

255. Заяви та листування про зміну віросповідання окремих осіб; 18901931

256. Розпорядження, заяви, листування та ін[ші] документи на дозвіл на споріднені одруження; 1890-1895

257. Розпорядження, заяви, листування та ін[ші] документи про оформлення записів в метричних книгах, зміну віросповідання, видачу свідоцтв та ін[ши]; 1896-1901

258. Розпорядження, заяви, листування та ін[ші] документи на дозвіл на споріднені одруження; 1896-1899

259. Розпорядження, заяви, листування та ін[ші] документи про оформлення записів в метричних книгах, зміну віросповідання, видачу свідоцтв та ін[ши]; 1900-1905

260. Розпорядження, заяви, листування та ін[ші] документи на дозвіл на споріднені одруження; 1900-1907

261. Листування з Галицьким намісництвом та ін[шіми] установами Львова про наведення довідок з метричних книг; 1903-1920

262. Розпорядження, заяви, листування та ін[ші] документи про оформлення записів в метричних книгах, зміну віросповідання, видачу свідоцтв та ін[ши]; 1906-1910 
263. Розпорядження, заяви, листування та ін[ші] документи на дозвіл на споріднені одруження; 1908-1920

264. Листування з Галицьким намісництвом, воєводським управлінням та ін[шіми] установами Львова про ведення метричних книг, видачу свідоцтв, надання звітності та ін[ши]; 1918-1931

265. Розпорядження, заяви, листування та ін[ші] документи на дозвіл на споріднені одруження; 1921-1931

\section{III. Списки парафій і парафіян}

266. Список вірменських парафій Галичини і Буковини та журнал обліку розпоряджень; 1782

267. Списки жителів юридик єпископських у Львові, які виконували повинність; 1812-1843

268. Списки парафіян Львова, які померли на інфекційні хвороби; 1831$-1833$

269. Списки парафіян та статистичні дані про них в Станіславському, Тернопільському воєводствах та на Буковині; 1841-1842

270. Списки мешканців в будинку митрополичої консисторії; 1841

271. Списки парафіян та статистичні дані про них в м-ку Городенка; 1782 $-1825$

272. Списки парафіян Городенківського повіту; 1822

273. Список громад поміщицьких маєтків парафії м. Городенка; 1898

274. Списки парафіян статистичні дані про них в м-ку Кути; 1782-1837

275. Те ж в м-ку Лисець; 1782-1825

276. Список парафіян в м. Снятин; 1782-1808

277. Список парафіян та приналежних сіл повіту Снятин; 1782-1837

278. Списки парафіян статистичні дані про них в м. Станіслав; 1822-1825

279. Список парафіян в Станіславському повіті; 1808

280. Те ж в м. Тисьмениця; 1808-1822

281. Те ж в м. Чернівцях; 1833

IV. Метричні книги парафій у Бережанах, Городенці, Кутах, Лисець, Львові, Станіслав[ов]і, Сучаві, Чернівцях

282. Виписки 3 метричних книг про смерть парафіян м. Бережани; 18691889

283. Метрична книга про народження, одруження, смерть парафіян м-ка Городенка; 1868-1897

284. Метрична книга про смерть парафіян с. Кути; 1868-1894

285. Метрична книга про народження, одруження, смерть парафіян м-ка Лисець; 1868-1891

286. Метрична книга Вірменського собору у Львові про народження парафіян; 1777-1893 
287. Метрична книга про народження, одруження, смерть парафіян м. Станіслав[ів]; 1880-1893

288. Те ж парафіян м. Сучава; 1833-1901

289. Метрична книга та виписки з свідоцтв парафіян м. Тисьмениця; 1832$-1895$

290. Метрична книга про народження, одруження, смерть парафіян м. Чернівці; 1881-1893

\section{V. Підготовка шематизмів і комплектування бібліотек}

291. Звіти про надіслання документів для складення шематизмів; 1782$-1816$

292. Листування з Крайовим губернаторством, Магістратом та ін[шими] установами м. Львова про складення звітності та підготовку до видання шематизмів; 1821-1829

293. Розпорядження, списки, листування про підготовку до видання шематизмів та діяльність парафій і бібліотек; 1830-1833

294. Те ж; 1834-1835

295. Листування з Галицьким губернським управлінням, Магістратом та ін[шими] установами Львова про підготовку до видання шематизмів та складення звітності; 1836-1840

296. Розпорядження, інструкції, листування та ін[ші] документи про складення звітності до шематизмів; 1840-1845

297. Те ж; 1846-1850

298. Те ж; 1851-1857

299. Те ж; $1858-1859$

300. Те ж; $1860-1863$

301. Те ж; 1864-1870

302. Те ж; 1871-1879

303. Розпорядження, інструкції, листування та ін[ші] документи про складення звітності до шематизмів, діяльність парафій і бібліотек та ін[ши]; 1907-1909

309. Те ж; 1910-1918

310. Розпорядження, інструкції, листування та ін[ші] документи про складення звітності до шематизмів, надходження релігійної літератури до бібліотек та ін[ши]; 1923-1931

311. Листування з Крайовим губернаторством у Львові, релігійними товариствами про видання релігійних та історичних книг; 1801-1840

312. Листування 3 Крайовим губернаторством та ін[шими] установами Львова про комплектування церковних бібліотек релігійними та історичними книгами; 1841-1850

313. Те ж; $1851-1860$

314. Те ж; 1861-1870

315. Список книг бібліотеки Вірменської консисторії; (П-а пол. ХІХ ст.) 
316. Статистичний звіт про стан церковних бібліотек в Станіслав[ів]ському повіті; 1840

317. Листування 3 львівськими видавництвами про передплату часописів і журналів; 1903-1933

\section{Cтатті}

318. Праця невстановленого автора про життя Ісуса Христа; б/д

319. Статті невстановленого автора про 500-річний ювілей заснування римо-католицького капітулу у Львові; б/д

320. Стаття невстановленого автора про історію картини Божої матері в м. Ченстохова; б/д

321. Рецензія невстановленого автора на книгу Пальмеро Аврелія „Російська церква"; б/д

322. Виписки з статей періодичних видань; „3 Тифлісу під Арарат”, „Ян Длугош”, „Князь Юрій Любомирський” та ін[ші]; 1866-1875

323. Стаття невстановленого автора „Про політичну агітацію серед населення"; б/д

324. Стаття невстановленого автора „Про опіку над дівчатами”; б/д

325. Стаття Кутбеши С. та ін[ших] авторів про життя польської королеви Ядвіги; б/д

326. Лист невстановленого кореспондента редактору журналу „Пшегльонд” у Львові про статті поміщенні в газетах з нагоди відбудови костьолу в с. Окопи; 1904

327. Примірник газети Центрального бюро „Червоного Хреста” у Відні; 1917

\section{ДОКУМЕНТИ ПРО МАЙНОВИЙ СТАН ФІНАНСОВО-ГОСПОДАРСЬКУ ДІЯЛЬНІСТЬ}

\section{I. Інвентарі}

328. Інвентарі описи майна костьолу в м. Бережани; 1787-1841

329. Те ж м-ка Городенка; 1791-1826

330. Інвентарі описи майна костьолу м-ка Кути; 1786-1815

331. Те ж м-ка Лисовець; 1785-1876

332. Те ж м. Луцьк; 1783

333. Те ж Вірменського собору у Львові; 1783-1873

334. Те ж архієпископської резиденції у Львові; 1783

335. Те ж вірменського костьолу м-ка Обержин; 1785

336. Те ж костьолу м. Снятин; 1820-1838

337. Те ж м. Станіслав; 1795-1818

338. Те ж с. Сучава; 1839

339. Те ж м. Тисьмениця; 1763-1831 
340. Статистичні звіти, списки, повідомлення та ін[ші] документи про рухоме і нерухоме майно костьолу в с. Яструбичі; 1832-1836

\section{II. Майновий стан церковних мастків і костьолів, земельні повинності, прибутки 3 церковних маєтків, спадщина}

341. Списки маєтків консисторії та дані про виконання земельних повинностей; б/д

342. Витяги з львівських гродських актових книг про майнові справи консисторії; 1513-1597

343. Витяг $з$ львівських і кам'янецьких гродських актових книг про майнові справи в с.с. Армяни, Жердє, Красноставці, Сатанів, їх розмежування та ін[ші]; 1557-1761

344. Листування з Крайовим губернаторством про укладення контрактів, оренду земельних ділянок та ін[ші] майнові справи; 1774-1794

345. Розпорядження, інвентарні описи, листування та ін[ші] про стан митрополичих і церковних маєтків; 1779-1784

346. Листування 3 Крайовим губернаторством, фінансовою палатою та ін[шими] установами Львова про майнову та фінансову діяльність вірменських костьолів у Галичині; 1783-1793

347. Листування з Крайовим губернаторством про укладення контрактів, оренду земельних ділянок та ін[ші] майнові справи; 1784-1799

348. Розпорядження Крайового губернаторства у Львові про збереження церковного майна в окружних касах; 1785

349. Листування з Крайовим губернаторством та Крайовим урядом Буковини про запис нерухомого майна, нормування земельних повинностей та ін[ші] майнові справи; 1792-1800

350. Листування 3 Крайовим губернаторством, фінансовою палатою та ін[шими] установами Львова про майнову та фінансову діяльність вірменських костьолів у Галичині; 1794-1800

351. Листування 3 Крайовим губернаторством, фінансовою палатою та ін[шими] установами Львова про майнову та фінансову діяльність вірменських костьолів у Галичині; 1801-1811

352. Листування з Крайовим губернаторством у Львові про догляд за церковним майном та надання дозволу на торгівлю у святкові дні; 1805$-1811$

353. Листування 3 Крайовим губернаторством, Магістратом Львова та ін[шими] установами про майнові справи парафій та зв'язки з конгрегацією „Де Пропаганда Фіде” в Римі; 1812-1816

354. Розпорядження Губернського, Крайового і Окружного управлінь у Львові про передачу церковного срібла та інвентарного опису цінностей Вірменського кафедрального собору; 1812-1819

355. Листування з Крайовим губернаторством у Львові про стан церковних маєтків, записи нерухомого майна у судові книги та ін[ши] майнові справи; 1818-1832 
356. Листування 3 Крайовим губернаторством, фінансовою палатою та ін[шими] установами Львова про майнову діяльність вірменських костьолів у Галичині; 1821-1832

357. Договори, судові рішення, листування та ін[ші] документи про майнову суперечку Вірменського капітулу у Львові і спадкоємцями Карпфа I.; $1830-1836$

358. Обіжник, повідомлення та ін[ші] документи про передачу церковного срібла державі та їх взаєморозрахунки; 1830

359. Розпорядження Крайового губернаторства у Львові про збереження церковного і монастирського майна та книги записів пожертвувань; $1830-1834$

360. Статистичні звіти, списки, повідомлення та ін[ші] документи про майнові справи вірменських костьолів Львівського воєводства; 1830-1835

361. Листування з Крайовим губернаторством у Львові про записи в судові книги нерухомого майна, встановлення земельних повинностей та ін[ші]; 18331836

362. Листування з Крайовим губернаторством у Львові, Крайовим урядом Буковини та ін[шими] установами про прибутки церковних маєтків, спадщину та ін[ши] майнові справи; 1836

363. Листування з Крайовим губернаторством у Львові, Крайовим урядом Буковини та ін[шими] установами про прибутки церковних маєтків, спадщину та ін[ши] майнові справи; 1837-1839

364. Листування з Крайовим губернаторством у Львові про записи в судові книги нерухомого майна, встановлення земельних повинностей та ін[ші]; 1837-1840

365. Листування з Крайовим губернаторством у Львові, Крайовим урядом Буковини та ін[шими] установами про прибутки церковних маєтків, спадщину та ін[ши] майнові справи; 1840-1847

366. Листування з Крайовим губернаторством і фінансовою прокуратурою у Львові про стан церковних маєтків, оренду нерухомого майна, встановлення земельних повинностей та ін[ші]; 1841

367. Листування з Крайовим губернаторством і фінансовою прокуратурою у Львові про стан церковних маєтків, оренду нерухомого майна, встановлення земельних повинностей та ін[ші]; 1842

368. Те ж; 1843-1854

369. Те ж; $1844-1845$

370. Те ж; $1846-1847$

371. Те ж; $1847-1850$

372. Листування з Крайовим губернаторством у Львові про відмову селян від повинностей та скасування кріпацтва у 1848 р.; 1848-1849

373. Листування з Крайовим губернаторством у Львові, Крайовим урядом Буковини та ін[шими] установами про прибутки церковних маєтків, спадщину та ін[ши] майнові справи; 1848-1850 
374. Листування з Крайовим губернаторством і фінансовою прокуратурою у Львові про стан церковних маєтків, оренду нерухомого майна, встановлення земельних повинностей та ін[ші]; 1850-1853

375. Листування з Крайовим губернаторством у Львові, Крайовим урядом Буковини та ін[шими] установами про прибутки церковних маєтків, спадщину та ін[ши] майнові справи; 1851-1855

376. Листування з Галицьким намісництвом, фінансовою прокуратурою та ін[шими] установами про стан церковних маєтків, оренду нерухомого майна, встановлення земельних повинностей та ін[ші]; 1855-1860

377. Листування з Галицьким намісництвом, Крайовим урядом Буковини та ін[шими] установами про прибутки церковних маєтків, спадщину та ін[ши] майнові справи; 1857-1860

378. Те ж; 1861-1863

379. Листування 3 Галицьким намісництвом, фінансовою палатою та ін[шими] установами Львова про стан церковних маєтків, оренду нерухомого майна, встановлення земельних повинностей та ін[ші]; 1861$-1865$

380. Листування з Галицьким намісництвом, Крайовим урядом Буковини та ін[шими] установами про прибутки церковних маєтків, спадщину та ін[ши] майнові справи; 1864-1870

381. Листування з Галицьким намісництвом, фінансовою прокуратурою та ін[шими] установами про стан церковних маєтків, оренду нерухомого майна, встановлення земельних повинностей та ін[ші]; 1868-1870

382. Розпорядження Галицького намісництва у Львові та Буковинського Крайового управління в Чернівцях про подання звітності з прибутків парафій для призначення податку; 1871-1873

383. Листування з Галицьким намісництвом, податковими управліннями та ін[шими] установами Львова про сплату податків з рухомого і нерухомого майна; 1872-1878

384. Листи Апостольської нунціатури у Відні про майнову і фінансову діяльність; 1875-1879

385. Те ж; $1880-1889$

386. Листування з вірменським костьолом про майнові та фінансові справи; $1880-1898$

387. Розпорядження, договори, листування та ін[ші] документи про майнові та фінансові справи вірменського костьолу в Галичині та Буковині; 1889-1895

388. Рахунки, відозви, листування та ін[ші] документи про пожертвування жителем м. Снятин Миколою М. земельної площі місцевому вірменському костьолові; 1890-1896

389. Листування з Святою конгрегацією пропаганди у Римі, Крайовим урядом Буковини та ін[шими] установами про одержання прибутків з нерухомого майна, пожертвування коштів та ін[ши]; 1890-1895

390. Розпорядження, повідомлення та ін[ші] документи про майновий стан вірменських костьолів і монастирів; 1908-1910 
391. Листування з Галицькою фінансовою прокуратурою у Львові про виділення земельної площі у с. Олешкові для потреб вірменської церкви та зміни в іпотечних книгах; 1910

392. Лист Буковинського крайового правління в Чернівцях про придбання речей релігійного культу, виготовлених в Австрії; 1813

393. Листування з Окружним земельним управлінням в м. Станіславі про право власності на нерухоме майно вірменських костьолів; 1923-1925

394. Розпорядження, рішення, листування та ін[ші] документи про стан нерухомого майна у Львівському і Станіславському воєводствах; 1923$-1935$

\section{III. Майнові справи вірмен}

395. Витяги 3 актових книг, постанов, розпоряджень, договорів та ін[шіх] документів про майнові справи львівських вірмен; 1586-1690

396. Те ж; 1701-1749

397. Те ж; 1753-1759

398. Те ж; 1762-1769

399. Те ж; $1770-1778$

400. Те ж; 1778

401. Те ж; 1779

402. Те ж; 1780

403. Те ж; 1781

404. Те ж; 1782

405. Те ж; 1782

406. Те ж; 1782

407. Те ж; 1783

408. Те ж; 1783-1786

409. Договори, контракти, плани будинків, листування та ін[ші] документи про продаж графом Потоцьким А. маєтку в с. Олексінцях баронові Гейделеві Р.; 1798-1836

410. Листування з Крайовим губернаторством у Львові і Папською нунцією у Відні про купівлю поміщицького маєтку в с. Дублянах; 1844-1845

411. Листування 3 повітовими судами Буковини про рішення спадкових справ вірмен; 1923-1931

\section{IV. Сплата податків}

412. Розпорядження, повідомлення, інструкції та ін[ші] документи про сплату податків приватними та духовними особами вірменських парафій Галичини; 1778-1791

413. Листування з Львівським Окружним управлінням і Магістратом про надіслання звітів про майновий стан і прибутки священнослужителів для їх оподаткування; 1784-1786 
414. Розпорядження, повідомлення, інструкції та ін[ші] документи про сплату податків приватними та духовними особами вірменських парафій Галичини; 1792-1798

415. Те ж; 1799-1800

416. Те ж; 1801-1811

417. Листування з крайовим губернаторством у Львові про нарахування та сплату прибуткового податку духовними особами; 1821-1831

418. Розпорядження, звіти, листування та ін. документи про нарахування та сплату податків духовними особами; 1821-1831

419. Листування з Губернським управлінням, Львівським магістратом та ін[шими] установами про сплату податків 3 нерухомого майна; 1830$-1835$

420. Розпорядження, звіти, листування та ін[ші] документи про нарахування та сплату податків духовними особами; 1833-1836

421. Розпорядження, звіти, листування та ін[ші] документи про нарахування та сплату податків духовними особами; 1837-1838

422. Те ж; $1839-1840$

423. Те ж; 1841-1843

424. Те ж; $1844-1845$

425. Те ж; $1846-1850$

426. Те ж; $1850-1859$

427. Те ж; $1860-1870$

428. Листування з Галицьким намісництвом у Львові про сплату податків духовними особами; 1880-1895

429. Розпорядження, списки, листування та ін[ші] документи про нарахування та сплату податків духовними особами; 1900-1905

430. Листування з Галицьким намісництвом у Львові, фінансовою прокуратурою у Чернівцях та ін[шими] установами про сплату податків 3 вірменських парафій; 1902-1910

431. Розпорядження, заяви, листування про нарахування на духовних осіб прибуткового податку; 1903-1920

432. Листування з Крайовим банком, дирекцією земельного кредитного товариства у Львові та ін[шими] установами про сплату податків, надання кредитів та ін[ши] фінансові питання; 1903-1920

433. Листування з Крайовим відділом у Львові та Повітовим комітетом у Дрогобичі про сплату церковного податку; 1904

434. Розпорядження, списки, листування та ін[ші] документи про сплату податків духовними особами; 1906-1907

435. Те ж; 1908-1910

436. Те ж про сплату податків 3 нерухомого майна; 1923-1933

437. Листування з Крайовим банком, дирекцією земельного кредитного товариства у Львові та ін[шими] установами про сплату податків, надання кредитів та ін[ши] фінансові питання; 1923-1933 


\section{V. Фінансово-господарська діяльність, страхування майна}

438. Листування з римською конгрегацією „Де Пропаганда Фіде” про фінансово-господарську діяльність консисторії; 1717-1722

439. Те ж; 1723-1782

440. Повідомлення Державної казни у Львові про фінансові розрахунки з боржниками і кредиторами; 1785-1786

441. Листування з Крайовим губернаторством у Львові про господарські та торгівельні справи; 1822-1824

442. Листування з Губернським управлінням, Фінансовою прокуратурою та ін[шими] установами Львова про фінансову діяльність; 1829-1835

443. Інструкції Губернського управління у Львові про передачу фінансових і бухгалтерських звітів державній бухгалтерії; 1830-1835

444. Листування з Крайовим губернаторством у Львові про господарські та торгівельні справи; 1835-1840

445. Листування з Галицьким намісництвом та Магістратом Львова про фінансово-господарський стан консисторії та парафіяльних будинків; $1851-1858$

446. Листування з Папською нунцією про фінансово-господарську діяльність консисторії; 1852-1859

447. Листування з Галицьким намісництвом та магістратом Львова про фінансово-господарський стан консисторії та парафіяльних будинків. Домові книги; 1859

448. Розпорядження, звіти, листування та ін[ші] документи про фінансовогосподарський стан консисторії та парафіяльних будинків; 1861-1871

449. Листування з магістратом Львова про господарську діяльність; 1872

450. Листування з Галицьким намісництвом у Львові та ін[шими] парафіяльними управліннями про фінансово-господарську діяльність; $1872-$ $-1878$

451. Листування з Галицьким намісництвом у Львові та ін[шими] парафіяльними установами про асигнування коштів на адміністративногосподарські потреби; 1872-1879

452. Річний фінансовий звіт вірменського капітулу; 1873

453. Листування з Галицьким намісництвом у Львові, парафіяльними управліннями та ін[шими] установами про фінансово-господарську діяльність; 1886-1889

454. Те ж; 1890-1894

455. Звіти про фінансову діяльність вірменських парафій Львівської дієцезії для отримання дотацій; 1894

456. Листування з Галицьким намісництвом у Львові, парафіяльними управліннями та ін[шими] установами про фінансово-господарську діяльність; 1896-1899

457. Листування з Галицьким намісництвом, парафіяльними управліннями та ін[шими] установами Львова про фінансову діяльність вірменських парафій для отримання дотацій; 1893-1899 
458. Розпорядження Галицького намісництва у Львові про складення статистичної звітності за 1897 р.; 1898

459. Звіти про фінансовий стан вірменських парафій львівської дієцезії для отримання дотацій; 1899

460. Листування з Галицьким намісництвом у Львові, Буковинським крайовим управлінням та ін[шими] установами про фінансово-господарську діяльність; 1900-1905

461. Листування з промисловими фірмами, товариствами та ін[шими] установами Відня, Кракова, Львова про їх фінансово-господарську діяльність; 1901-1910

462. Листування з парафіяльними комітетами про фінансово-господарський стан вірменських костьолів в Галичині і на Буковині; 1903-1920

463. Листування 3 Галицьким намісництвом, парафіяльними правліннями та ін[шими] установами про господарську діяльність; 1904-1918

464. Листування 3 парафіяльними управліннями Галичини і Буковини про фінансовий стан вірменських костьолів і монастирів; 1905-1906

465. Листування з Галицьким намісництвом у Львові, Буковинським крайовим управлінням та ін[шими] установами про фінансово-господарську діяльність; 1906-1910

466. Листування з Галицьким намісництвом, Крайовим банком у Львові та ін[шими] установами про фінансову діяльність; 1913-1918

467. Листування 3 Галицьким намісництвом, Крайовим комітетом та ін[шими] установами Львова про виділення коштів на будівництво костьолів, утримання шкіл, надання матеріальної допомоги священикам та ін[ші]; 1913-1917

468. Листування з вірменським парафіяльним управлінням у Бережанах про фінансово-господарську діяльність; 1917-1918

469. Звіт про фінансово-господарську діяльність костьолу у Станіславі; 1917

470. Розпорядження, кошториси, листування та ін[ші] документи про фінансово-господарську діяльність; 1921-1932

471. Листування з Міністерством освіти, Львівським воєводством та парафіяльними управліннями про асигнування коштів на адміністративногосподарські потреби; 1923-1925

472. Страхові поліси товариства взаємних забезпечень у Кракові; 1873

473. Розпорядження, списки, листування та ін[ші] документи про страхування майна від стихійного лиха; 1888-1890

474. Поліси Товариства взаємних забезпечень у Кракові про страхування майна Вірменського капітулу у Львові; 1925

\section{VI. Підписка на державну позику}

475. Листування з Крайовим губернаторством у Львові про участь духовенства у підписці на державну позику; 1794-1798

476. Те ж; $1810-1816$ 
477. Листування з Галицьким намісництвом у Львові про участь духовенства і парафіян в підписці на державну позику; 1854-1855

478. Листування з Галицьким намісництвом і Крайовим комітетом у Львові про виплату виграшів на облігації крайової позики; 1905-1909

479. Обіжник, повідомлення, листування про розповсюдження облігацій крайової позики серед населення; 1925-1931

\section{VII. Прибутки і витрати}

480. Касові розрахунки про прибутки з дзвіниці та витрати на обслуговування; 1799-1808

481. Статистичні дані про прибутки і витрати консисторії; 1870-1872

482. Листування з Галицьким намісництвом у Львові, парафіяльними управліннями та ін[шими] установами про прибутки і витрати вірменських парафій; 1890-1892

483. Книга реєстрації прибутків і витрат вірменських парафій; 1893-1903

484. Звіт про прибутки і витрати вірменської парафії у Бережанах; 1887

485. Звіт про прибутки і вірменської парафії в м. Кути; 1882

486. Звіти про витрати вірменського костьолу в м. Луцьку; 1783

487. Книга реєстрації витрат вірменського кафедрального собору у Львові; 1855

488. Звіт про прибутки і витрати вірменської парафії у м. Снятині; 1887

489. Фінансові звіти парафії в м. Станіслав[ів]; 1876-1889

490. Звіти про витрати коштів на купівлю будинків для приміщення Папської нунції у Варшаві; 1925

\section{VIII. Ломбардний банк „Піус Монс”}

491. Статути ломбардного банку „Піус Монс” при вірменському кафедральному соборі у Львові; б/д

492. Регламент про обов’язки керівництва ломбардного банку „Піус Монс” при Вірменському кафедральному соборі у Львові; 1907

493. Інструкція для керівництва банку „Піус Монс” у Львові; 1927

494. Інструкція про ведення діловодства ломбардного банку „Піус Монс” при Вірменському кафедральному соборі у Львові; б/д

495. Касові звіти, листування та ін. документи про фінансову діяльність ломбардного банку „Піус Монс” у Львові та у вірменських парафіях в м.м. Городенці, Замості, Снятині; 1777-1786

496. Розпорядження, звіти, листування та ін. документи про взаєморозрахунки вірменських парафій з банком „Піус Монс” у Львові; 1779-1791

497. Звіт про трирічну діяльність ломбардного банку „Піус Монс” при Вірменському костьолі в м-ку Лисець; 1786

498. Розпорядження, звіти, листування та ін[ші] документи про фінансові розрахунки вірменських парафій з банком „Піус Монс” у Львові; 1792$-1800$ 
499. Розпорядження, звіти, листування та ін[ші] документи про фінансові розрахунки вірменських парафій з банком „Піус Монс” у Львові; 18011811

500. Те ж; 1821-1830

501. Те ж; 1832-1838

502. Листування з банком „Піус Монс” у Львові про фінансові розрахунки та заява службовців банку з проханням про надання їм матеріальної допомоги; 1833-1835

503. Розпорядження, звіти, листування та ін[ші] документи про фінансові розрахунки вірменських парафій з банком „Піус Монс” у Львові; 1839$-1840$

504. Те ж; 1841-1844

505. Те ж; $1845-1847$

506. Те ж; $1848-1850$

507. Те ж; 1851-1852

508. Те ж; $1853-1858$

509. Те ж; 1859-1860

510. Те ж; $1861-1862$

511. Те ж; 1863

512. Те ж; 1864-1867

513. Те ж; $1868-1870$

514. Листування з галицьким намісництвом про фінансову діяльність банку „Піус Монс" у Львові; 1872-1879

515. Листування Крайового суду з банком „Піус Монс” у Львові про перелік заставлених речей та відомості про їх охорону; 1873-1876

516. Фінансові звіти банку „Піус Монс” у Львові; 1876

517. Дані про асигнування коштів приватними особами в банк „Піус Монс” на вірменський костьол в м. Снятині; 1876

518. Повідомлення Галицького намісництва про фінансову діяльність банку „Піус Монс" у Львові; 1880-1883

519. Листування 3 державними організаціями та приватними особами про фінансові розрахунки з банком „Піус Монс” у Львові; 1885-1895

520. Баланс за 1887-1888 рр. банку „Піус Монс” у Львові 1888-1889

521. Листування з Галицьким намісництвом про фінансову діяльність банку „Піус Монс" у Львові; 1890-1901

522. Те ж; 1901-1919

523. Листування з Галицьким намісництвом про реорганізацію банку „Піус Монс" у Львові; 1902-1905

524. Списки осіб, які заповідали кошти в банк „Піус Монс” у Львові для проведення поминальних панахид; 1912

525. Фінансовий звіт банку „Піус Монс”; 1930-1931

526. Листування з Галицьким намісництвом про платні службовцям банку „Піус Монс" у Львові; 1890-1892

527. Пенсійна справа Богданович К., вдови службовця банку „Піус Монс” у Львові; 1831-1835 
528. Листування з Галицьким намісництвом про надання матеріальної допомоги Захаревичу В., працівникові банку „Піус Монс” у Львові; 1876

529. Справа про звинувачення директора банку „Піус Монс” Мардиросевича Я. в розтрачанні державних грошей; 1901

\section{IX. Пожертвування на костьоли і монастирі}

530. Розпорядження, договори, листування та ін документи про пожертвування коштів для вірменських костьолів і монастирів в Галичині і на Буковині; 1830-1835

531. Те ж; 1872-1878

532. Те ж; 1880-1883

533. Листування 3 парафіяльними управліннями Львівського і Станіслав[ів]ського воєводств про пожертвування коштів для вірменських костьолів; 1880-1883

534. Розпорядження, договори, листування та ін[ші] документи про пожертвування коштів для вірменських костьолів і монастирів в Галичині і на Буковині; 1886-1888

535. Розпорядження, договори, листування та ін[ші] документи про пожертвування коштів для вірменських костьолів і монастирів в Галичині і на Буковині; 1889-1890

536. Те ж; 1891-1892

537. Те ж; 1893

538. Те ж; 1894-1895

539. Те ж; 1896-1899

540. Те ж; 1900-1902

541. Листування з Міністерством віросповідань і освіти у Варшаві, Галицьким Намісництвом та ін[шими] установами про пожертвування коштів на вірменські костьоли; 1902-1914

542. Розпорядження, договори, листування та ін[ші] документи про пожертвування коштів для вірменських костьолів і монастирів в Галичині і на Буковині; 1903-1904

543. Рахунки, акти, листування та ін[ші] документи про пожертвування коштів для вірменських костьолів в Галичині і на Буковині; 1905-1908

544. Розпорядження, договори, листування та ін[ші] документи про пожертвування коштів для вірменських костьолів і монастирів в Галичині і на Буковині; 1907-1910

545. Рахунки, акти, листування та ін[ші] документи про пожертвування коштів для вірменських костьолів; 1909-1911

546. Розпорядження, договори, листування та ін[ші] документи про пожертвування коштів для вірменських костьолів і монастирів в Галичині і на Буковині; 1911-1918

547. Рахунки, акти, листування та ін[ші] документи про пожертвування коштів для вірменських костьолів. Список фондів пожертвувань; 1912$-1917$ 
548. Листи вірменських парафіяльних управлінь Галичини про пожертвування коштів для вірменських костьолів; 1922-1931

549. Списки осіб, які вносили кошти для вірменських костьолів Галичини; б/д

550. Акт про пожертвування коштів для вірменського костьолу в м. Бережанах; 1884

551. Листування з священиком Косінським про незаконний продаж будинку, пожертвуваного вірменському костьолу в м. Бережанах; 1886-1888

552. Акти про пожертвування коштів для вірменського костьолу в м-ку Городенка; 1864-1913

553. Рахунки, акти, листування та ін[ші] документи про пожертвування коштів Богосевичем Б. і Богосевичем Р. для вірменського костьолу в м. Кути; 1906-1912

554. Рахунки, акти, листування та ін[ші] документи про пожертвування поміщиком Давидовичем Г. коштів для костьолу в м. Кути; 1911-1913

555. Списки осіб, які вносили кошти для вірменського костьолу в м. Лисець; 1785

556. Списки осіб, які вносили кошти на користь вірменського кафедрального собору у Львові; 1785

557. Журнал обліку пожертвувань для вірменського собору у Львові; 1801$-1846$

558. Угода, декларація, листування та ін[ші] документи про пожертвування коштів Августовичем Л. для вірменського костьолу у Львові; 1834$-1914$

559. Рахунки, відзиви, листування та ін[ші] документи про пожертвування коштівдля вірменського собору у Львові; 1902-1904

560. Листування 3 податковим управлінням у м. Станіслав про пожертвування коштів для вірменського костьолу; 1903-1913

\section{X. Галицький релігійний фонд}

561. Листування з Окружним управлінням та ін[шими] установами про заснування і бюджет фонду; 1789-1792

562. Список релігійних фондів в Галичині та на Буковині і їх бюджет; 1830

563. Звіти, баланси, листування та ін[ши] документи про фінансову діяльність фонду - том I; 1852-1854

564. Те ж- том II і останній; 1855-1859

565. Звернення та листування про пожертвування коштів на утримання монастирської лікарні „Братів милосердя” в м. Брно (Моравія); 1852-1853

XI. Участь духовенства у зборі коштів на допомогу бідним і потерпілим від стихійного лиха

566. Листування з Крайовим губернаторством у Львові про участь духовенства в зборі коштів на допомогу бідним та потерпілим від стихійного лиха; 1786-1796

567. Те ж; $1797-1800$ 
568. Те ж; 1801-1811

569. Те ж; 1812-1816

570. Те ж; 1821-1829

571. Те ж; 1830-1835

572. Те ж; 1836-1840

573. Те ж; 1841-1842

574. Те ж; 1843-1850

575. Те ж; 1851-1854

576. Те ж; 1855-1860

577. Те ж; 1861-1863

578. Листування з Галицьким намісництвом та ін[шими] установами Львова про пожертвування коштів на добродійні цілі; 1861-1868

579. Листування з Галицьким намісництвом про участь духовенства в зборі коштів на допомогу бідним та потерпілим від стихійного лиха; 18641870

580. Листування 3 Крайовим комітетом, парафіяльними правліннями та ін[шими] установами Львова про збір коштів на благодійні цілі; 18731878

581. Листування $з$ Галицьким намісництвом та ін[шими] установами про збір коштів на благодійні цілі; 1890-1895

582. Листування з Галицьким намісництвом у Львові та ін[шими] установами про збір коштів на благодійні цілі; 1896-1912

583. Листування з Галицьким намісництвом у Львові та ін[шими] установами про збір коштів на релігійні потреби та благодійні цілі; 1913-1918

584. Звернення комітету допомоги в м. Бжесько про збір коштів для потерпілих від пожежі; 1904

РОЗПОРЯДЖЕННЯ, ІНСТРУКЦЇ̈, КОШТОРИСИ, ЛИСТУВАННЯ ТА ІНШІ ДОКУМЕНТИ ПРО БУДІВНИЦТВО, РЕСТАВРАЦЮ I РЕМОНТ КОСТЬОЛІВ, КАПЛИЦЬ І ПАРАФІЯЛЬНИХ БУДИНКІВ

\section{I. В Галичині й Буковині}

585. Розпорядження, інструкції, кошториси та листування про ремонт парафіяльних та будинків Львівського повіту; 1791-1799

586. Листування з Крайовим губернаторством та Магістратом Львова про ремонт приміщення консисторії та парафіяльних будинків; 1801-1815

587. Листування 3 Крайовим губернаторством у Львові про будівництво і ремонт вірменських костьолів і парафіяльних будинків; 1812-1816

588. Розпорядження, інструкції, кошториси, листування та ін. документи про асигнування коштів на ремонт і реєстрацію вірменських костьолів і парафіяльних будинків; 1821-1829

589. Листування з духовними особами про будівництво, ремонт і реставрацію вірменських костьолів, монастирів і парафіяльних будинків в Галичині; 1831-1835 
590. Розпорядження, інструкції, листування та ін[ші] документи про асигнування коштів на ремонт та будівництво вірменських костьолів і парафіяльних будинків; 1834-1840

591. Листування з Крайовим губернаторством у Львові і крайовим урядом Буковини про будівництво та ремонт вірменських костьолів в Галичині і на Буковині; 1836-1840

592. Листування з Крайовим губернаторством і Магістратом Львова про ремонт приміщень консисторії, парафіяльних будинків та шкіл; 1841$-1850$

593. Листування з Крайовим губернаторством у Львові та духовними особами про будівництво та ремонт вірменських костьолів і каплиць в Галичині та на Буковині; 1841-1850

594. Те ж; 1852-1859

595. Листування з Галицьким намісництвом у Львові, комітетом будівництва вірменських костьолів в м. Чернівцях та з духовними особами про будівництво та ремонт костьолів і монастирів; 1861-1879

596. Лист Тернопільського окружного суду з проханням про асигнування коштів на будівництво каплиці для в'язнів; 1872-1872

597. Листування з Галицьким намісництвом, парафіяльними управліннями та ін. установами про асигнування коштів на будівництво, ремонт і реставрацію вірменських костьолів, монастирів і парафіяльних будинків; $1880-1883$

598. Те ж; 1887-1895

599. Те ж; 1896-1899

600. Те ж; 1901-1910

601. Рішення, кошториси, листування та ін[ші] документи про будівництво та ремонткостьолів і парафіяльних будинків; 1903-1920

602. Розпорядження Буковинського крайового уряду у Чернівцях про асигнування коштів на збереження старовинних храмів; 1914

603. Листування з Галицьким намісництвом про асигнування коштів на відбудову костьолів, монастирів, парафіяльних будинків в Галичині; 1917$-1918$

604. Розпорядження, кошториси, листування та ін[ші] документи про асигнування коштів на ремонт та реставрацію вірменських костьолів, монастирів і парафіяльних будинків в Галичині; 1923-1931

\section{II. В Бережанах}

605. Листування 3 парафіяльним управлінням про асигнування коштів на ремонт костьолу; 1918

\section{III. У Городенці}

606. Листування з парафіяльним управлінням про реставрацію церковних будинків; 1902-1917 


\section{IV. В Кутах}

607. Листування з Крайовим губернаторством у Львові про будівництво вірменського костьолу; 1786, 1839-1842

\section{V. В Лисовець}

608. Листування з парафіяльним управлінням про ремонт костьолу та парафіяльних будинків; 1918

VI. У Львові

609. Плани, кошториси, листування та ін[ші] документи про реставрацію вірменського костьолу; 1904-1909

610. Листування 3 Галицьким намісництвом, Магістратом Львова та ін[шими] установами про виділення коштів на ремонт і реставрацію вірменського костьолу; 1910-1934

611. Плани будівництва каплиці та допоміжних будівель при вірменському костьолі; 1931

612. Листування з Крайовим управлінням збереження пам'ятників архітектури і мистецтва у Кракові про звільнення вірменського костьолу від здачі кольорового металу на військові цілі; 1918

613. Лист Міністерства громадських робіт у Варшаві про передачу релігійних атрибутів вірменському костьолу; 1924

\section{VII. У Снятині}

614. Листування 3 парафіяльним управлінням про реставрацію церковних будинків; 1913-1914

\section{VIII. У Тисьмениці}

615. Лист місцевого пароха про ремонт вірменського костьолу; 1842

\section{B Cараєво}

616. Листування з Галицьким намісництвом про збір коштів на будівництво костьолу; 1913

\section{XI. Розпорядження, обіжник та листування про збереження церковних i історичних пам'яток}

617. Розпорядження Крайового губернаторства у Львові про збереження старовинних пам'яток і монет; 1812 
618. Листування з державними та церковними установами про збереження історичних і культурних пам'яток; 1830-1833

619. Листування з Галицьким намісництвом, Промисловим музеєм, Крайовим археологічним товариством та ін[шими] установами Львова про збереження історичних і культурних пам'яток; 1881-1889

620. Листування з Галицьким намісництвом, Австрійським музично-театральним товариством у Відні та ін[шими] установами про збереження історичних і культурних пам'яток; 1890-1910

621. Розпорядження Галицького намісництва і Львівського воєводського управління про охорону церковних пам'яток та предметів релігійного культу; 1903-1925

622. Обіжник Центральної комісії з охорони пам'ятників архітектури у Відні та розпорядження Буковинського управління про збереження старовинних храмів і церковних цінностей в Галичині і Буковині; 1913-1917

623. Розпорядження Міністерства віросповідань і мистецтва у Відні про інвентаризацію пам’яток мистецтва в церквах і костьолах для передачу їх на збереження; 1914

624. Листування 3 консерваторським відділом у Кракові про історичну вартість органів; 1917

\section{ДОКУМЕНТИ ПРО ДІЯЛЬНІСТЬ ЖІНОЧОГО МОНАСТИРЯ БЕНЕДИКТИНОК}

625. Розпорядження, заяви, листування та ін[ші] документи про діяльність монастиря; 1784-1796

626. Те ж; 1801-1829

627. Звіти про фінансові витрати монастиря; 1819-1833

628. Розпорядження, заяви, листування про прийом та навчання в монастиpi; 1829-1834

629. Листування з Крайовим губернаторством про фінансову діяльність монастиря; 1831-1899

630. Протокол перевірки діяльності монастиря; 1832

631. Розпорядження, звіти, листування та ін[ші] документи про релігійновиховну діяльність, ведення фінансових справ та ін. монастиря; 1834$-1839$

632. Розпорядження, заяви, листування та ін[ші] документи про діяльність монастиря; 1836-1842

633. Розпорядження, звіти, листування та ін[ші] документи про релігійновиховну діяльність, ведення фінансових та ін[ших] справ монастиря; 1840-1842

634. Те ж; 1843-1850

635. Те ж; 1851-1859

636. Те ж; 1861-1870

637. Фінансовий звіт за 1872 р.; 1872-1873 
638. Листування з Галицьким намісництвом про виникнення пожежі в монастирі; 1872-1873

639. Листування з Галицьким намісництвом про дозвіл на вступ приватних осіб до монастиря; 1881-1883

640. Протокол перевірки діяльності монастиря; 1883

641. Листування з Галицьким намісництвом про записи в іпотечних книгах земельних площ монастиря; 1887

642. Листування 3 Галицьким намісництвом про вступ приватних осіб до монастиря, фінансові справи та ін[ші]; 1894-1895

643. Листування 3 Галицьким намісництвом про фінансову діяльність монастиря; 1901-1909

644. Розпорядження, звіти, листування про фінансово-господарські справи монастиря; 1903-1920

645. Листування з монахинями монастиря про надання дозволу на релігійні обряди; 1905-1910

646. Повідомлення Галицького намісництва про відмову монахиням у безплатному переїзді; 1906

647. Листування 3 Галицьким намісництвом про обмін земельними ділянками між Львівським університетом і монастирем; 1912-1914

648. Перелік документів про діяльність монастиря; 1917

649. Листування з управлінням монастиря про асигнування коштів на його утримання; 1917

650. Листування з Галицьким намісництвом, Земельно-кредитним товариством про фінансово-господарську діяльність монастиря; 1918-1931

651. Листування з монастирем про стан шкільного будинку та сплату грошей за навчання; 1923-1932

652. Лист окружного судді Львова про фінансові зловживання ігумені монастиря; 1936

653. Характеристики і свідоцтва монахинь Бенедиктинок у Львові; 18281834

654. Листування з Крайовим губернаторством про призначення вчителів до школи монастиря Бенедиктинок у Львові; 1828-1834

655. Листування з Крайовим губернаторством і монастирем Бенедиктинок у Львові про зловживання владою ігуменею Колюмбою Н.; 1833-1834

656. Листування з Галицьким намісництвом про кількість монахинь в монастирі Бенедиктинок у Львові. Списки; 1891-1895

657. Листування з Галицьким намісництвом про обрання ігумені монастиря Бенедиктинок у Львові; 1894

658. Заяви монахинь монастиря Бенедиктинок про допущення та звільнення від обітниці; 1929-1931

659. Список монахинь монастиря Бенедиктинок у Львові; 1876

660. Особова справа Марамороша К. катехита монастиря Бенедиктинок у Львові; 1821-1855 


\section{ДОКУМЕНТИ ДІЯЛЬНОСТІ НАВЧАЛЬНИХ ЗАКЛАДІВ}

\section{I. Вірменської духовної семінарії}

661. Листування з Крайовим губернаторством у Львові про прийом та навчання студентів, надання стипендій та ін[ші]; 1784-1799

662. Те ж про зарахування та звільнення студентів; 1801-1814

663. Те ж про прийом та навчання, призначення на посаду вчителя та ін[ші]; $1812-1814$

664. Те ж про прийом та навчання іноземних студентів; 1812-1813

665. Те ж про зарахування та звільнення студентів та ін[ші]; 1821-1824

666. Те ж; 1828-1829

667. Розпорядження, заяви, листування та ін[ші] документи про зарахування студентів, плату за навчання та ін[ші]; 1835-1839

668. Те ж про зарахування студентів; 1840-1842

669. Те ж; 1843-1846

670. Те ж; $1847-1849$

671. Те ж про зарахування та звільнення студентів; 1852-1859

672. Листування з Галицьким намісництвом про зарахування студентів; 1861-1868

673. Відозви та листування про зарахування та надання стипендій студентам з релігійного фонду; 1873-1880

674. Відозви, зведення та листування про оголошення конкурсу на призначення стипендій семінаристам із фонду ерцгерцога Людовіка; 18791889

675. Листування з Галицьким намісництвом про надання семінаристам матеріальної допомоги з релігійного фонду; 1880-1889

676. Розпорядження, заяви, листування та ін[ші] документи про зарахування студентів, надання стипендій та ін[ши]; 1881-1889

677. Зведення, заяви, листування та ін[ші] документи про зарахування студентів; 1890-1895

678. Розпорядження, заяви, листування та ін[ші] документи про призначення стипендій та надання матеріальної допомоги 3 релігійного фонду семінаристам та студентам теологічного факультету Львівського університету; 1892-1899

679. Листування 3 Галицьким намісництвом, Крайовим комітетом та ін[шими] установами Львова про надання матеріальної допомоги семінаристам та студентам теологічного факультету Львівського університету; 1902-1910

680. Розпорядження Галицького намісництва про введення предмету гігієни в семінарії; 1914

681. Листування з Галицьким намісництвом, Крайовим комітетом про надання семінаристам матеріальної допомоги з релігійного фонду; 1918

682. Розпорядження, заяви, листування про зарахування та звільнення студентів; 1923-1931 
683. Свідоцтва успішності та характеристики семінаристів Духовних семінарій у Відні та Львові; 1830-1835

684. Заяви кандидатів про зарахування їх до семінарії; 1830-1835

685. Списки семінаристів-вірмен, які навчалися у Римо-католицькій духовній семінарії у Львові; 1834-1835

686. Списки, посвідчення, повідомлення про висвячення семінаристів на монахів; 1881-1895

687. Заяви та листування про зарахування до семінарії; 1901-1910

688. Список семінаристів, які проживали в будинку Римо-католицької семінарії і у жіночому монастирі Бенедиктинок; 1902

689. Заяви випускників про їх висвячення і вступ до монастиря; 1932-1935

690. Заяви, свідоцтва та ін[ші] документи про зарахування Аксентовича А. до семінарії; 1906

691. Заяви, свідоцтва та ін[ші] документи про зарахування Аксентовича Я. до семінарії; 1904

692. Те ж Богосевича В.; 1888

693. Те ж Давидовича Б.; 1878-1879

694. Те ж Манусевича С.; 1891-1901

695. Особова справа семінариста Марамороша А.; 1828-1832

696. Листування з Галицьким намісництвом про навчання в семінарії Пйотровича В.; 1888

697. Конспект з літератури і історії Вірменії семінариста Теодоровича 3.; 1897

\section{II. Навчального закладу ім. Торосевича}

698. Розпорядження, звіти, листування та ін[ші] документи про діяльність; 1872-1898

699. Листування з Святою конгрегацією пропаганди віри в Римі і Галицьким намісництвом про призначення священнослужителів опікунами закладу; 1904-1905

700. Листування з Крайовим банком про взаєморозрахунки; 1904

701. Звіт про фінансово-господарську діяльність; 1912-1913

702. План поверхів бурс; 1914

703. Листування про діяльність закладу; 1924-1933

704. Фінансовий звіт; 1929-1931

705. Список вихованців; 1903-1904

\section{III. Початкових і середніх шкіл}

706. Розпорядження, звіти, листування та ін[ші] документи про будівництво i ремонт вірменських початкових шкіл, заміщення вакантних посад вчителів і катехитів та ін[ші]; 1802-1811 
707. Листування з Крайовим губернаторством про організацію навчання; $1812-1816$

708. Розпорядження Крайового губернаторства про основні правила зарахування до початкових шкіл, семінарій і монастирів; 1813

709. Розпорядження, звіти, листування та ін[ші] документи про будівництво i ремонт початкових шкіл, заміщення вакантних посад вчителів, катехитів та ін[ші]; 1821-1829

710. Листування з Крайовим губернаторством у Львові про діяльність шкіл; $1830-1834$

711. Заяви та листування про заміщення вакантних посад катехитів; 1830$-1835$

712. Листування з Крайовим губернаторством у Львові про організацію навчання з релігії; 1832-1835

713. Розпорядження, звіти, листування та ін[ші] документи про будівництво і ремонт шкіл, заміщення вакантних посад вчителів і катехитів та ін[ші]; 1834-1839

714. Те ж; $1840-1843$

715. Те ж; $1844-1850$

716. Те ж; $1851-1859$

717. Те ж; 1861-1870

718. Розпорядження, зведення, листування та ін[ші] документи про збір коштів на розвиток початкових шкіл; 1872

719. Повідомлення, зведення та листування про заміщення вакантних посад катехитів та ведення навчання релігії в школах; 1881-1889

720. Те ж; 1890-1901

721. Листування з Крайовою і міською шкільними радами про ведення навчання релігії в школах; 1902-1909

722. Лист священика парафії м-ка Лисець $з$ проханням ліквідувати магазин спиртних напоїв, розміщеного в будинку школи. Малюнок будинку (акварель); 1905

723. Листування з дирекціями початкових і середніх шкіл про ведення навчання релігії; 1925-1934

\section{IV. Львівського університету}

724. Конкурсні питання з теології; 1816

725. Повідомлення про надання стипендій з релігійного фонду студентам теологічного і філософського факультетів; 1830-1835

726. Заяви, листування та ін[ші] документи про надання матеріальної допомоги 3 релігійного фонду студентам теологічного факультету; 1832$1835,1909-1918$

727. Розклади занять та іспитів теологічного та філософського факультетів; 1835,1909

728. Повідомлення Галицького намісництва про заповнення дипломів випускникам теологічного факультету; 1905-1906 
729. Листування з староством м. Заліщики про відбуття військової повинності слухачем теологічного факультету Торосевичем С.; 1906-1907

\section{V. Вірменської колегії в Римі}

730. Заяви листи про зарахування на теологічний факультет; 1930-1931

\section{VI. Католицького університету в Любліні}

731. Рахунки та листи про асигнування коштів на утримання університету; 1924-1925

VII. Курсів для духовенства в Познані

732. Повідомлення Спілки священиків „Уніта” в м. Познані про організацію курсів; 1930-1931

\section{VIII. Університету у Фрайбурзі}

733. Листування з випускником університету Деповським Й. про його висвячення; 1913

\section{IX. Закладу сестер родини Марії}

734. Повідомлення Галицького намісництва про діяльність закладу в с. Лімна та асигнування на його утримання; 1904

\section{Х. Лісотехнічної школи}

735. Листування з дирекцією Вищої лісотехнічної школи у Львові про надання дозволу на практичні заняття студентів в лісах консисторії; 1918

\section{XI. Курсів акушерок}

736. Розпорядження, списки, листування про організацію курсів та проведення практики; 1814

\section{XII. Академії мистецтв у Кракові}

737. Листування 3 ректором академії про надання матеріальної допомоги з фондів закладу ім. Торосевича студенту Межовичу Т.; 1912 


\section{СТАТУТИ, РОЗПОРЯДЖЕННЯ, ІНСТРУКЦІЇ, ЗВІТИ, ЛИСТУ- ВАННЯ ТА ІН[ШІ] ДОКУМЕНТИ СПІВПРАЦІ 3 ТОВАРИСТВАМИ}

738. Листування з Крайовим губернаторством про антидержавну діяльність таємних товариств та відношення до них духовенства; 1801-1802

739. Те ж про діяльність таємних товариств та заходи проти них; 1813-1840

740. Листування з Крайовим губернаторством і Крайовим урядом Буковини про діяльність Конгрегації мехітаристів православних вірмен в м. Сучаві; 1818-1829

741. Розпорядження, інструкції листування та ін[ші] документи про діяльність Конгрегації мехітаристів православних вірмен в м. Сучаві; 1835 1840

742. Листування з Крайовим губернаторством у Львові про збір внесків католицькими товариствами, надання дозволу на виїзд в Персію та ін[ші]; 1842-1849

743. Повідомлення Крайового губернаторства про заснування товариства „Підтримки католицької акції в Америці”; 1829

744. Листування 3 Крайовим губернаторством та ін[шими] установами Львова про діяльність католицьких релігійних товариств та інститутів; $1835-1840$

745. Розпорядження, звіти, листування та ін[ші] документи про діяльність католицьких місій в країні та за кордоном; 1842

746. Статути, розпорядження, листування та ін[ші] документи про діяльність „Марійського товариства” у Львові та ін[ших] релігійних організацій - том I; 1851-1853

747. Те ж - том II і останній; 1854-1860

748. Розпорядження, звіти, листування та ін[ші] документи про релігійну діяльність „Марійського товариства” у Львові та ін[ших] католицьких організацій в Африці і Азії та участь у цій місії вірменського костьолу; 1861-1870

749. Листування з Крайовим губернаторством про відновлення діяльності Крайового музичного товариства у Львові; 1852

750. Статут та повідомлення про заснування Зоологічного товариства у Відні; 1858

751. Листування з релігійними організаціями у Відні, Кракові, Львові та ін[ших] містах про їх діяльність; 1870-1876

752. Лист львівської комісії з організації загальної виставки у Відні до співпраці; 1872

753. Відозва Комітету для погорільців в м-ку Болехові про надання матеріальної допомоги; 1876

754. Статут, розпорядження, листування та ін[ши] документи про заснування та діяльність товариства Червоного Хреста у Львові; 1880-1909

755. Листування з парафіяльним управлінням в м. Станіславі про заснування Товариства опіки; 1881-1882 
756. Статут, списки, листування та ін[ші] документи про призначення делегатів на вибори Головного управління товариства „Сільськогосподарський гурток"; 1889-1908

757. Звернення редактора журналу „Католицьке товариство” про членство у товаристві; 1889

758. Листи товариства „Святої конгрегації пропаганди віри” в Римі про зміну обряду, ведення метричних книг, сплату церковних податків та iн[ші]; 1890-1896

759. Листування 3 парафіяльними управліннями і релігійними товариствами про розповсюдження католицької релігії серед інших народів; 1891$-1893$

760. Листування з Польським видавничим у Кракові про розповсюдження священиками релігійних книг та укріплення католицької віри серед населення; 1891

761. Запрошення, програми, листування про участь товариств у зборах і засіданнях; 1903-1928

762. Повідомлення Комітету про урочисте відкриття пам'ятника Міцкевичу А. у Львові; 1904

763. Листування з Магістратом Львова про заснування товариства „Центральний комітет справ добродійств християнських"; 1904

764. Повідомлення священика про заснування „Польської читальні” у м-ку Лисець; 1904

765. Статут, програма, розпорядження про організацію роботи 1-го Конгресу захисту дітей і молоді у Відні; 1906-1907

766. Листування з релігійними товариствами у Кракові та Львові про пожертвування коштів на потреби церкви, поширення віри серед населення та ін[ші]; 1906-1910

767. Листування 3 релігійними товариствами про їх заснування та діяльність; 1908-1918

768. Відозва „Спілки промислової і релігійної молоді” в Кракові про підтримку громадою науково-виховних закладів для бідних дітей та організацію виставки літургічного промислу; 1909-1920

769. Листи екскурсійного бюро „Карл Гиренбах” в м. Віллах (Австрія) про організацію паломництва до Єгипту і Палестини; 1910

770. Статут австрійського релігійного товариства „Католітен Уніон” у м. Брно; 1911

771. Звіт про діяльність секції „Опіки над польськими солдатами” при єпископському комітеті у Кракові; 1917

772. Рахунки, квитанції, листи та ін[ші] документи про пожертвування коштів на благодійне товариство св. Иосифа священиком Щепанським К. в м-ку Лисець; 1917

773. Статут товариства „Унія християнства” у Варшаві; 1922

774. Звіт „Східно-галицького товариства охорони дітей і молоді у Львові” за 1918-1923 pp. та запрошення делегата вірменського комітету на засідання; 1924 
775. Листи про діяльність релігійних товариств у Львові та Познані; 19251931

776. Розпорядження, листування та ін[ші] документи про заснування та діяльність товариств; 1929-1931

777. Лист священика м. Бережани про дотримання товариствами і організаціями моральних норм в костьолі; 1930

778. Звіт про діяльність польської християнської демократичної партії у Варшаві; 1932

779. Розпорядження, оголошення, інструкції, листування та ін[ші] документи про заходи проти поширення інфекційних захворювань та участь духовенства в пропаганді дотримання гігієни серед населення - том I; $1792-1822$

780. Те ж- том II і останній; 1823-1917

РОЗПОРЯДЖЕННЯ, ПОВІДОМЛЕННЯ, ЛИСТУВАННЯ ТА ІНШ ДОКУМЕНТИ

\section{I. Про військову службу, облік військовозобов'язаних, призначення ка- пеланів, релігійну роботу в армії}

781. Листування з Крайовим губернаторством у Львові про виконання жителями військового обов'язку; 1793-1800

782. Те ж про обов'язки військових капеланів та ін[ші]; 1801-1811

783. Розпорядження та листування про обов'язки військово службовців, надання їм допомоги та ін[ші]; 1813-1815

784. Розпорядження та інструкції про виконання священиками військового обов' язку; 1826-1838

785. Листування з Крайовим губернаторством у Львові про надіслання списків військовозобов'язаних, ведення обліку та ін[ші]; 1841-1842

786. Те ж про набір військовозобов'язаних, призначення капеланів та ін[ші]; $1843-1850$

787. Листування з Галицьким намісництвом та Крайовим урядом Буковини про призначення капеланів та організацію їх роботи, ведення обліку військовозобов'язаних та ін[ші]; 1861-1870

788. Те ж про ведення релігійної роботи в армії; 1872-1878

789. Листування з військовим командуванням у Львові про виконання священиками військового обов'язку та ведення релігійної роботи в армії; 1883-1889

790. Листування з Міністерством оборони та магістратами Львова і Чернівців про виконання священиками військового обов'язку, призначення пенсій військовим інвалідам та ін[ші]; 1904-1918 
791. Листування 3 Галицьким намісництвом, вірменським парафіяльним управлінням та ін[шими] установами Львова про надання матеріальної допомоги священикам, звільнення їх від військової служби та ін[ші]; 1917-1918

792. Пояснення до інструкції Міністерства зовнішніх справ для допризовників; 1918

793. Листування з Станіславським воєводством про звільнення священиків від військової служби до закінчення навчання; 1925-1931

II. Про використання приміщень релігійного культу та дзвонів для військових потреб

794. Лист Львівського окружного управління про передачу єзуїтського костьолу у Львові австрійській військовій владі; 1786

795. Листування з Крайовим губернаторством у Львові про використання господарських приміщень для військових потреб; 1787-1788

796. Листування з Окружним урядом та Магістратом Львова про розміщення військового госпіталю в колишньому Театинському монастирі; 1790$-1791$

797. Розпорядження Міністерства віросповідань і освіти та Галицького намісництва про покриття дахів дерев'яних храмів жерстю і передачу мідних покрівель для військових потреб; 1917

798. Розпорядження Консерваторського відділу у Кракові та військового управління у Львові про передачу дзвонів з вірменських костьолів для військових потреб; 1917

799. Листування з парафіяльними управліннями в мм. Бережанах і Станіславові про придбання дзвонів взамін знятих російськими солдатами під час військової окупації та ін[ші]; 1923-1925

\section{III. Про перебування російських військ в Галичині}

800. Повідомлення Президіального управління у Львові про перебування російських військ в Галичині; 1809

801. Виписки з газети „Прикарпатська Русь” про перебування російських військ в Галичині; 1914

802. Розпорядження та повідомлення про передплату воєнних позик; 19141918

803. Звернення жителів Люблінського воєводства до папи Бенедикта XV про звільнення їх родин з полону; 1915

ДОКУМЕНТИ ПРО ПРИЗНАЧЕННЯ, ЗВІЛЬНЕННЯ СВЯЩЕНИКІВ, НАДАННЯ ВІДПУСТОК, НАРАХУВАННЯ ПЛАТНІ, НАДАННЯ ПРАВ НА БОГОСЛУЖІННЯ, ДИСЦИПЛІНАРНІ СТЯГНЕННЯ, СПИСКИ, ОСОБОВІ СПРАВИ 
I. Розпорядження, заяви, листування та ін[ші] документи про призна чення, переміщення, звільнення священиків, надання їм відпусток та матеріальної допомоги

804. Повідомлення екзаменаційної комісії Крайовому Губернаторству у Львові про результати конкурсних екзаменів на заміщення вакантних посад священиків; 1772-1786

805. Заяви, розпорядження, листування та ін[ші] документи про оголошення конкурсу на заміщення вакантних посад священиків в Галичині і на Буковині; 1792-1797

806. Конкурсні питання з релігії на заміщення вакантних посад священиків; 1786

807. Розпорядження, заяви, листування про призначення, переміщення і звільнення священиків, надання їм матеріальної допомоги та ін[ші]; 1783$-1793$

808. Те ж; 1798-1800

809. Заяви, розпорядження, листування та ін[ші] документи про оголошення конкурсу на заміщення вакантних посад священиків в Галичині і на Буковині; 1801-1811

810. Заяви, розпорядження, листування та ін[ші] документи про оголошення конкурсу на заміщення вакантних посад священиків в Галичині і на Буковині; 1812-1817

811. Розпорядження, заяви, листування про призначення, переміщення та звільнення священиків, надання їм матеріальної допомоги та ін[ші]; $1820-1829$

812. Заяви, розпорядження, листування та ін[ші] документи про оголошення конкурсу на заміщення вакантних посад священиків в Галичині і на Буковині; 1820-1829

813. Розпорядження, заяви, листування про призначення, переміщення і звільнення священиків, надання їм матеріальної допомоги та ін[ші]; 1830$-1934$

814. Розпорядження, заяви, повідомлення про оголошення конкурсів на заміщення вакантних посад священиків; 1830-1835

815. Питання та тексти відповідей конкурсних екзаменів з релігії на заміщення вакантних посад священиків; 1833-1835

816. Розпорядження, заяви, листування про призначення, переміщення та звільнення священиків, надання їм матеріальної допомоги та ін[ші]; 1835

817. Заяви, розпорядження, листування та ін[ші] документи про оголошення конкурсу на заміщення вакантних посад священиків в Галичині і на Буковині; 1835-1841

818. Розпорядження, заяви, листування про призначення, переміщення та звільнення священиків, надання їм матеріальної допомоги та ін[ші]; 1836-1837 
819. Розпорядження, заяви, листування про надання священикам відпусток та матеріальної допомоги; 1836-1840

820. Розпорядження, заяви, листування про призначення, переміщення та звільнення священиків, надання їм матеріальної допомоги; 1838-1839

821. Те ж; 1840-1849

822. Заяви, розпорядження, листування та ін[ші] документи про оголошення конкурсу на заміщення вакантних посад священиків в Галичині і на Буковині; 1843-1849

823. Те ж; $1850-1860$

826. Те ж; 1861-1862

827. Розпорядження, заяви, листування про надання священикам відпусток та матеріальної допомоги; 1861-1868

828. Розпорядження, заяви, листування про призначення, переміщення та звільнення священиків, надання їм матеріальної допомоги; 1863-1870

829. Розпорядження, заяви, листування про призначення, переміщення та звільнення священиків, надання їм матеріальної допомоги; 1872-1878

830. Те ж; 1876

831. Те ж; 1879-1883

832. Листи і телеграми духовних і світських осіб з прізвищами на букви А-Я про призначення, переміщення з посад, надання матеріальної допомоги та ін[ші]; 1884-1910

833. Розпорядження, заяви, листування про призначення, переміщення та звільнення священиків, надання їм матеріальної допомоги; 1887-1889

834. Те ж; 1891-1895

835. Лист до Галицького намісництва про заміщення вакантної посади каноніка вірменського собору у Львові; 1891

836. Розпорядження, заяви, листування про призначення, переміщення та звільнення священиків, надання їм матеріальної допомоги; 1896-1899

837. Те ж; 1900-1904

838. Заяви, розпорядження, листування та ін[ші] документи про оголошення конкурсу на заміщення вакантних посад священиків в Галичині і на Буковині; 1901-1906

839. Листування з Галицьким намісництвом та ін[шими] установами про надання священикам матеріальної допомоги;

840. Розпорядження, заяви, листування про призначення, переміщення та звільнення священиків, надання їм матеріальної допомоги; 1905

841. Те ж; 1906-1907

842. Заяви, розпорядження, листування та ін[ші] документи про оголошення конкурсу на заміщення вакантних посад священиків в Галичині і на Буковині; 1908-1914

843. Розпорядження, заяви, листування про призначення, переміщення та звільнення священиків, надання їм матеріальної допомоги; 1908-1910

844. Те ж; 1911-1918 
845. Листування 3 парафіяльними правліннями в мм. Лисець, Станіслав, Тисьмениця про призначення на посади священиків, видачу платні з релігійного фонду та ін[ші]; 1913-1917

846. Листування 3 парафіяльним управлінням м. Кути про надання житла та матеріальної допомоги священнослужителям; 1913-1918

847. Листування з Галицьким намісництвом про призначення на посади священиків, надання їм матеріальної допомоги та ін[ші]; 1914

848. Листування з Львівським воєводством та ін[шими] установами про надання відпусток священикам, витрату коштів на їх лікування та ін[ші]; 1923-1931

849. Заяви, розпорядження, листування та ін[ші] документи про оголошення конкурсу на заміщення вакантних посад священиків в Галичині і на Буковині; 1923-1931

II. Розпорядження, заяви, листування та ін[ші] документи про нарахування священнослужителям платні, пенсій, надання дотацій

850. Розпорядження, заяви, листування та ін[ші] документи про нарахування священнослужителям платні, пенсій, надання дотацій та ін[ші]; $1784-1791$

851. Те ж; $1792-1800$

852. Те ж; 1801-1809

853. Те ж; $1810-1811$

854. Те ж; 1812-1816

855. Те ж; $1820-1824$

856. Те ж; $1828-1829$

857. Те ж; 1830-1834

858. Те ж; $1835-1838$

859. Те ж; $1839-1842$

860. Те ж; $1843-1847$

861. Те ж; $1848-1850$

862. Те ж; $1851-1853$

863. Те ж; $1854-1859$

864. Те ж; $1860-1863$

865. Те ж; $1864-1870$

866. Те ж; 1871-1878

867. Розпорядження, заяви, листування та ін[ші] документи про нарахування священнослужителям платні, пенсій, надання дотацій та ін[ші]; 1880-1889

868. Те ж; 1890-1899

869. Те ж; 1901-1905

870. Те ж; 1906-1910

871. Те ж; 1913-1918

872. Те ж; 1923-1931 
III. Повідомлення та листування про відзначення священнослужителів за сумлінну працю

873. Листування з Крайовим губернаторством у Львові про відзначення священнослужителів; 1775-1800

874. Те ж; 1801-1814

875. Те ж; $1827-1859$

876. Листування з Галицьким намісництвом про відзначення священнослужителів; 1863-1929

877. Повідомлення Галицького намісництва про нагородження монахиньсанітарок польового госпіталю; 1917-1918

IV. Розпорядження, зведення, листування про надання священикам прав богослужінь

878. Розпорядження, зведення, листування про надання священикам прав на богослужіння, релігійні обряди та ін[ші]; 1780-1793

879. Те ж; 1794-1800

880. Розпорядження, зведення, листування про надання священикам прав на богослужіння, релігійні обряди та ін[ші]; 1801-1815

881. Те ж; 1821-1829

882. Те ж; $1829-1833$

883. Те ж; 1834-1835

884. Те ж; 1836-1840

885. Те ж; $1841-1842$

886. Те ж; $1843-1845$

887. Те ж; 1846-1850

888. Те ж; 1851-1860

889. Те ж; 1861-1870

890. Те ж; 1872-1879

891. Те ж; 1880-1889

892. Те ж; 1890-1895

893. Те ж; 1896-1899

894. Те ж; 1901-1918

895. Те ж; 1906-1910

896. Те ж; 1918-1931

\section{V. Дисциплінарні справи на священиків}

897. Листування з Галицьким губернським управлінням про ведення слідства 3 дисциплінарних справ священиків; 1786-1811

898. Те ж; $1818-1832$

899. Листування з Крайовим губернаторством у Львові про ведення слідства 3 дисциплінарних справ священиків; 1836-1840 
900. Скарги парафіян на священиків про привласнення церковного майна, порушення виконання обрядів, аморальну поведінку та ін[ші]; 1843$-1849$

901. Те ж; 1851-1859

902. Те ж; $1861-1870$

903. Те ж; $1871-1876$

904. Те ж; 1831-1889

905. Листування з галицьким намісництвом, парафіяльними управліннями та ін[шими] установами про зловживання священиками службовими обов'язками; 1896-1898

906. Те ж; 1904-1931

\section{VI. Списки, особові справи, листування та ін[ші] документи з особового} складу

907. Виклики на Духовний суд у Львові священиків в справі зловживання своїми службовими обов'язками; 1631-1680

908. Повідомлення та листування про смерть священнослужителів в Галичині і на Буковині; 1795-1873

909. Списки священиків Львівської і Чернівецької єпархій; 1812-1834

910. Списки священиків м. Кути та статистичні дані про них; 1872-1873

911. Списки вірменських священиків, які отримали матеріальну допомогу; 1917

912. Особова справа священика Баронча Д.; 1830-1876

913. Листування з військовим польовим відділом з релігійних справ про видачу паспорта капелану Босевичу В. і переведення його у запас; 1892

914. Особова справа священика Демського В.; 1922-1924

915. Те ж священика Карковського Ф.; 1910-1918

916. Те ж Косінського Я.; 1878-1905

917. Те ж священика Мардиросєвича Й.; 1880, 1904

918. Те ж священика Марамороша Ю.; 1892-1896

919. Листування з Крайовим губернаторством у Львові про надіслання інформацій про капелана Матійовича; 1875

920. Повідомлення канцелярії Примаса Польщі у м. Познань про перебування в країні підозрілого священика Млинарчука з Каліфорнії; 1931

921. Особова справа священика Мошоро С.; 1786

922. Справа Мошоро М., священика м. Лисець, звинуваченого в привласненні церковного майна; 1791-1799

923. Розпорядження, протоколи, листування та ін[ші] документи про розгляд дисциплінарної справи священиків Мошоро Г. і Біши М.; 1840$-1850$

924. Листування з Крайовим губернаторством і дирекцією Львівської поліції про дозвіл на виїзд священика Піюсгюльгіяна М. з Венеції в Константинополь; 1821 
925. Лист староства м. Богородчан про надання священику Плевчинському В. австрійського підданства; 1908

926. Особова справа священика Ромашкана М.; 1882-1918

927. Те ж священика Следзьовського I.; 1908-1918

928. Те ж священика Швайгера Л.; 1923

929. Те ж священика Яськевича А.; 1911-1912

\section{ДОКУМЕНТИ ДІЛОВОДСТВА І ПОШТОВОГО ЗВ'ЯЗКУ}

930. Журнал реєстрації обіжників консисторії; 1819-1832

931. Розпорядження Галицького губернського управління про ведення діловодства; 1841-1842

932. Листування 3 Львівським воєводським управлінням про правильне оформлення службових документів, розшук книг цивільного стану та ін[ші]; 1923-1931

933. Листування з парафіяльними управліннями в м.м. Бережанах і Станіславі про облік рекомендованої кореспонденції; 1924

934. Журнал реєстрації вхідної кореспонденції; 1783-1784

935. Журнал реєстрації вхідної і вихідної кореспонденції; 1806-1819

936. Те ж; $1825-1833$

937. Журнал реєстрації вхідної кореспонденції; 1825-1827

938. Те ж; 1835-1836

939. Журнал реєстрації вхідної і вихідної кореспонденції; 1844-1858

940. Те ж; 1849-1863

941. Журнал реєстрації вхідної кореспонденції; 1859-1868

942. Журнал реєстрації вхідної і вихідної кореспонденції; 1863-1873

943. Те ж; $1868-1881$

944. Те ж; 1890-1903

945. Листування з Галицьким губернським управлінням у Львові про ведення поштового діловодства; 1801-1811

946. Те ж; 1821-1829

947. Розпорядження, повідомлення та листування про ведення поштового діловодства; 1833-1835

948. Листування з Галицьким намісництвом про ведення поштового діловодства; 1852-1859

949. Те ж; 1861-1870

950. Обіжники та інструкції про користування поштовим зв'язком; 1830$-1835$

951. Повідомлення дирекції поштового і телеграфічного управління у Львові про користування поштовим зв' язком; 1830-1835

952. Повідомлення дирекції поштового і телеграфічного управління у Львові про перевірку поштових повноважень; 1904

953. Розпорядження та листування про поштові оплати та зразки єпископських печаток і гербів; 1830-1832 
954. Розпорядження та листування про поштові оплати за пересилання листів, посилок та ін[ші]; 1838-1840

955. Те ж; $1843-1850$

956. Розпорядження та листування про поштові оплати за пересилання залізницею; 1851-1853

957. Інвентарні описи № 1, 2; 1953

958. Інвентарний опис $1 ; 1966,1968,1975-1976$

\section{DAS INVENTARVERZEICHNIS DES ARCHIVS DER KURIE DER ARMENISCH-KATHOLISCHEN ERZDIÖZESE IN LEMBERG FÜR DIE JAHRE 1616-1939}

\section{Zusammenfassung}

Die Anfänge der armenisch-katholischen Erzdiözese Lwów (Lemberg) reichen bis ins 17. Jahrhundert zurück, denn am 24. Oktober 1630 legte Bischof Mikołaj Torosowicz in Lemberg das katholische Glaubensbekenntnis ab und begab sich damit unter die Jurisdiktion des Heiligen Stuhls. Vorher hatte dort seit 1356 die armenische Diözese Lemberg funktioniert, die vom armenischen Katholikos von Sis für die in Ruthenien ansässige armenische Bevölkerung erigiert worden war.

Hinsichtlich ihrer geographischen Lage erstreckte sich die Erzdiözese Lemberg über das südöstliche Gebiet der Adelsrepublik. Im Jahre 1665 verfügte sie über 15 Pfarreien, 20 Priester und etwa 300 Gläubige. Mit den Jahren verbesserte sich dieser Zahlenstand beträchtlich; so gab es zum Beispiel 1763 schon 18 Pfarreien mit fast 6000 Katholiken, und 1772 zählte die Gebiete Polens, Litauens, Moldawiens und der Walachei umfassende Erzdiözese 22 Pfarreien, 40 Priester und etwa 6000 Gläubige. Negative Veränderungen brachten diesbezüglich die Teilungen Polens im 18. Jahrhundert mit sich, in deren Gefolge die innerhalb der Grenzen des russischen Teilungsgebiets gelegenen Pfarreien in den Jahren 1809-1816 der Jurisdiktion eines besonderen Administrators unterstellt wurden. Im österreichischen Teilungsgebiet wiederum wurden infolge der willkürlichen Politik des Josephinismus 6 armenische Pfarreien liquidiert, eine auch den Gläubigen des lateinischen Ritus zugesprochen und 2 Pfarreien aus der Bukowina der Lemberger Erzdiözese zugeschlagen. Weitere Veränderungen erbrachte das 20. Jahrhundert. Nach dem Vertrag von Riga im Jahre 1921 und insbesondere kraft des 1925 geschlossenen Konkordats der Republik Polen mit dem Heiligen Stuhl ging die Bukowina an Rumänien verloren, und die dortigen Pfarreien wurden der Jurisdiktion des Lemberger Erzbischofs entzogen. Eine positive Veränderung bildete dagegen die Ausdehnung seiner Jurisdiktion auf das Gebiet der gesamten Zweiten Republik. In der Zwischenkriegszeit 1918-1939 verfügte die Erzdiözese Lemberg armenisch-katholischen Ritus' über 8 Pfarreien im Rahmen von 3 Dekanaten, 9 Pfarrkirchen und 19 Kapellen, an denen 18 Priester die ungefähr 5000 Gläubigen (1939) religiös betreuten.

In der armenisch-katholischen Erzdiözese in Lemberg wirkten mehrere wichtige kirchliche und sozial-religiöse Institutionen. So wurde 1803 ein Domkapitel ins Leben 
gerufen, und in den Jahren 1665-1784 prosperierte in Lemberg ein von den Theatinern geleitetes Päpstliches Armenisches Kolleg, das sich mit der intellektuellen und sittlichen Vorbereitung der Priesteramtskandidaten befasste. Mit dem Blick auf ärmere männliche Jugendliche wurde in der zweiten Hälfte des 19. Jahrhunderts das Józef-Torosiewicz-Internat in Lemberg gegründet (es existierte von 1865 bis 1939). Von 1940 bis 1945 genoss das Institut „Mons Pius” hohes Ansehen, das sich mit den finanziellen Angelegenheiten und Bankeinlagen der polnischen Armenier befasste. Und 1930 wurde der Erzdiözesanverband der Armenier ins Leben gerufen. Geschätzte Periodika in polnischer Sprache waren zwei Zeitschriften: der von 1927 bis 1934 monatlich erscheinende „Posłaniec św. Grzegorza” (,Sankt-Georgs-Bote”) sowie die Zweimonatsschrift „Gregoriana”, die von 1935 bis 1938 erschien. Und schließlich muss noch auf die Präsenz und das Wirken des Ordens der Benediktinerinnen armenisch-katholischen Ritus' in der Erzdiözese Lemberg verwiesen werden, der seit dem 17. Jahrhundert eine Mädchenschule in Lemberg leitete, deren Abschlüsse ab 1889 staatlich anerkannt wurden.

Im Verlauf von vier Jahrhunderten wurde die Erzdiözese Lemberg armenisch-katholischen Ritus' von 12 Erzbischöfen regiert. Das Ende des Bestehens einer armenischen Ortskirche in Lwów erfolgte mit dem Tod von Erzbischof Józef Teodorowicz am 4. Dezember 1938. Die Amtsgeschäfte übernahm damals der Kapitularvikar Infulat Dionizy Kajetanowicz, aber der Ausbruch des Krieges und die politischen Veränderungen nach der Konferenz von Jalta hinderten den Heiligen Stuhl daran, einen neuen Oberhirten zu nominieren. Nach dem Ende des 2. Weltkrieges begannen die sowjetischen Behörden damit, die Strukturen der armenischen Erzdiözese in Lemberg durch Terror, Erpressung und Verhaftungen zu liquidieren. Vier Geistliche befanden sich in Gefängnissen und Lagern, von denen einer - Pater Kajetanowicz - starb. Die übrigen Priester und auch die Laien wurden gezwungen, ihre Wirkungsstätten im östlichen Kleinpolen (Galizien) zu verlassen; zum Teil kamen sie ins Gefängnis, oder sie wurden nach Polen repatriiert. Der Lemberger Dom und auch die übrigen armenischen Gotteshäuser wurden geschlossen und alle Institutionen liquidiert. Damit hörte die armenisch-katholische Erzdiözese Lemberg zu existieren auf, obwohl sie vom Heiligen Stuhl nie formal annulliert worden ist.

Das hier veröffentlichte Inventarverzeichnis der Archivalien der Lemberger Erzdiözesankurie armenisch-katholischen Ritus' berücksichtigt die gegenwärtig im Staatlichen Historischen Zentralarchiv der Ukraine in Lviv, Abteilung 475, aufbewahrten Quellen. Es enthält 958 Inventareinheiten in einem guten Dutzend Themenabteilungen: 1) Sitzungsprotokolle des Konsistoriums (der Kurie) und des Bischofskollegiums; 2) königliche Dekrete zu Angelegenheiten der armenisch-katholischen Kirche; 3) Quellen zur Geschichte der Armenier und der armenisch-katholischen Kirche; 4) Hirtenbriefe der Bischöfe; 5) Dekrete des Lemberger Gouverneurs, des Statthalters von Galizien und der zuständigen Wiener Ministerien; 6) Anordnungen und die Korrespondenz der Kurie mit staatlichen Stellen auf zentraler und lokaler Ebene; 7) kirchlich-religiöse Feierlichkeiten; 8) das Funktionieren der Pfarreien und Gotteshäuser; 9) vermögensrechtliche und wirtschaftliche Fragen; 10) Kirchenbau; 11) das armenisch-katholische Benediktinerinnenkloster; 12) Lehr- und Erziehungsanstalten; 13) Zusammenarbeit mit Vereinen; 14) Personaldokumente; 15) „Medienarbeit”; 16) verschiedene Archivalien. 